\title{
Review Article \\ Biodiversity of Terrestrial Ecosystems in Tropical to Temperate Australia
}

\author{
Raymond L. Specht \\ Department of Botany, The University of Queensland, Brisbane, QLD 4072, Australia \\ Correspondence should be addressed to Raymond L. Specht, r.specht@uqconnect.net
}

Received 19 September 2011; Revised 25 December 2011; Accepted 17 January 2012

Academic Editor: Panos V. Petrakis

Copyright () 2012 Raymond L. Specht. This is an open access article distributed under the Creative Commons Attribution License, which permits unrestricted use, distribution, and reproduction in any medium, provided the original work is properly cited.

During the short period of annual foliage growth in evergreen plant communities, aerodynamic fluxes (frictional, thermal, evaporative) in the atmosphere as it flows over and through a plant community determine the Foliage Projective Covers and leaf attributes in overstorey and understorey strata. The number of leaves produced on each vertical foliage shoot depends on available soil water and nutrients during this growth period. The area of all leaves exposed to solar radiation determines net photosynthetic fixation of the plant community throughout the year. In turn, the species richness (number of species per hectare) of both plants and resident vertebrates is determined. The species richness of unicellular algae and small multicellular isopods in permanent freshwater lagoons in Northern Australia may possibly have been increased by radiation released from nearby uranium deposits. Evolution of new angiosperms probably occurred in refugia during periods of extreme drought. When favourable climates were restored, the vegetation expanded to result in high Gamma Biodiversity (number of plant species per region) but with each major plant community having essentially the same species richness (number of plant species per hectare). The probable effects of pollution and Global Warming on biodiversity in Australian ecosystems, that experience seasonal drought, are discussed.

\section{Introduction}

During the 1920s to 1940s, scientists in the Botany Department and Waite Agricultural Research Institute of the University of Adelaide (together with scientists of CSIRO Soils Division and the South Australian Museum) studied many aspects of the climate, soils, vegetation, fauna, and Aborigines in South Australia as well as on the rest of the continent of Australia [1].

In 1935, the holistic concept of the "ecosystem" was promoted by Tansley, Professor of Botany of Oxford University [2]. The "ecosystem" concept, relating climate, soils, and vegetation, over time (short- and long-term) was pursued by Crocker of CSIRO Soils Division and the Agronomy Department of the Waite, together with Professor Wood of the Botany Department.

During 1947 and 1948 while on sabbatical leave in Cambridge University and the University of California, Berkeley, Crocker developed the concepts of "soil genesis and the pedogenic factors" and their interactions with the dynamics of plant communities_-in space and time [3]. The various ecophysiological facets of the ecosystem were to be explored and integrated by one scientist:

$$
\begin{array}{r}
\text { Vegetation }=\text { Function }(\text { climate, parent material, } \\
\text { relief, organisms, time }) .
\end{array}
$$

The holistic study of the dynamic processes that operate throughout the life cycle-from regeneration to maturity to senescence-of ecosystems in soil-vegetation chronosequences, post-fire succession, secondary succession after disturbance, and so forth, was initiated in the 1950s as the discipline of community-physiology.

The discipline of community-physiology attempts to study the processes that determine the complex interrelations of the many plants, animals, and microorganisms that form each ecosystem - quite distinct from descriptive studies of the component species of the whole ecosystem or the study of individual species within an ecosystem, termed ecophysiology and population ecology. Physicochemical processes (aerodynamic fluxes, available soil water, and mineral nutrition) determine the structure, growth, and biodiversity 
of intact plant communities (and associated consumers and decomposers) that comprise the diversity of ecosystems in the field.

\section{Gondwanan Soil Heritage}

On the super-continent of Gondwanaland during the Late Cretaceous, high rainfall of the tropical to subtropical summer degraded clay minerals in the soils to kaolinite, a clay in which phosphate ions are trapped within its crystalline lattice-structure thus making them unavailable to microorganisms and plant roots. Today, 50 million years later, remnants of these lateritic soils (tropical lateritic earths and subtropical lateritic podzols) still persist on the peneplain topography of all Gondwanan continents (Figure 1).

Although tectonic movement and climate change during the Cainozoic have eroded the Gondwanan lateritic soils, the original kaolinitic clays have been incorporated into modern-day soils where they are still able to bind phosphate in an unavailable form [4]. Pattern Analysis, PATN, of foliar nutrients ( $\mathrm{P}, \mathrm{K}, \mathrm{Ca}$, and $\mathrm{Mg}$ ) in 154 samples of overstorey leaves collected from plant communities in eastern Australia identified three major nutrient groups (nutrient-rich, medium-nutrient, and nutrient-poor) that were then further divided into seven relatively "homogeneous" groups (Alison Specht, in [5, pp. 282-286]). The nitrogen level and nitrate reductase activity in leaves are closely correlated with the level of foliar phosphorus [6-8]. The vegetation on the remnants of lateritic podzols in southern Australia and on sandstone soils and Quaternary sands that are widespread in Australia are all very nutrient-poor. Even the soils on which medium-nutrient savanna open-forests and woodlands have persisted require superphosphate fertilizer for agricultural development. It is only the vegetation on recent basaltic soils that can be regarded as nutrient-rich.

\section{Gondwanan Vegetation Heritage}

The development of the Gondwanan vegetation in the Late Cretaceous through the Cainozoic-palynological studies initiated by Cookson in the University of Melbourne in the 1940s [13-16] — was traced by Martin in the University of New South Wales and by Dettmann in the University of Queensland [17-29]. Fossil pollen grains preserved in the brown coal deposits of the Early Tertiary reveal that the Gondwanan Antarctic beech, Nothofagus subsection brassii, today found in New Caledonia and New Guinea, was widely spread in southern Australia [14-16, 19-26]; limited numbers of pollen grains of the temperate Nothofagus subsections fusca and menziesii were found in the same deposits. Subtropical rainforest species in the palaeontological record included the Protead genera Gevuina, Knightia, Macadamia, and others [29]. Southern Gondwanan families such as Myrtaceae, Proteaceae, Restionaceae, Poaceae possess a subtropical to tropical heritage $[30,31]$. Fossil pollen grains of the typically Australian genus Eucalyptus have been found in the fossil records of the southern parts of Gondwanan

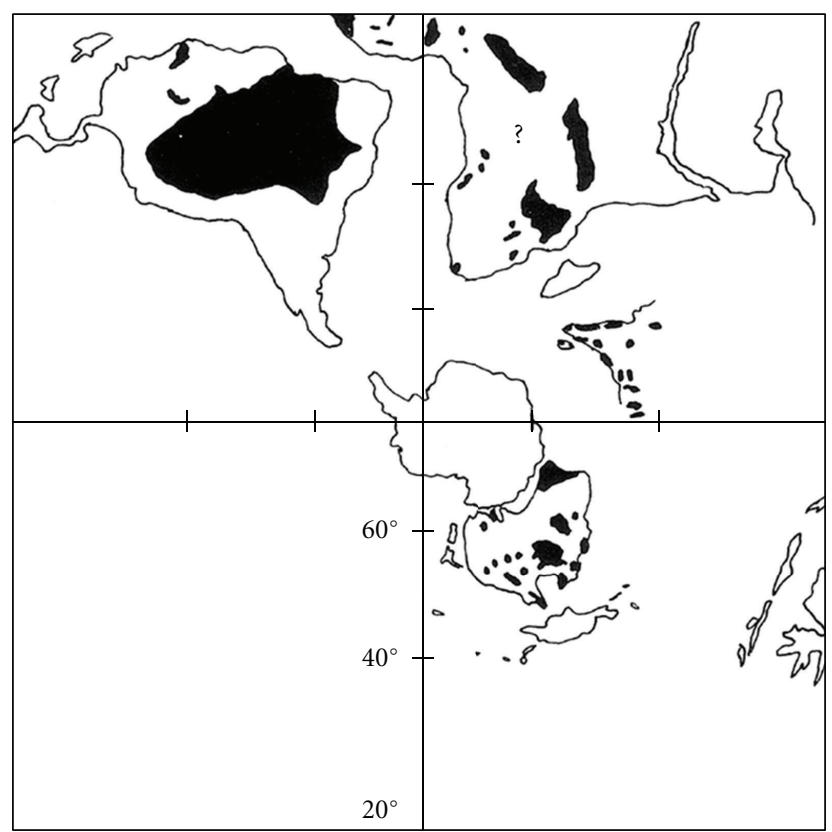

Figure 1: Distribution of lateritic soils (latosols) on the continental masses of Gondwanaland ([9-11], see [5, Figure 6.3]). The location of the Gondwanan land masses in the Late Cretaceous, 80 million years ago, is shown on a stereographic projection of the Southern Hemisphere between latitude $20^{\circ} \mathrm{S}$ to the South Pole [12].

continents, South America, Australia, and New Zealand [32-35].

In the Early Tertiary when the Australian continent separated from Antarctica, temperate rainforest vegetation, dominated by Nothofagus, became widespread over the southern and south-eastern part of the continent $[13,26,36]$; in nutrient-poor habitats, sclerophyllous heathy elements existed [29]. Tropical rainforest flora existed in the wettest areas of the north and north-east [37, 38]. Gondwanan C4 grasses and associated flora must have been widespread in the warmer north of the continent $[31,39-42]$, while some $14 \%$ of the present-day sandstone flora contains woody species in common with the sandstone flora of India (Figure 2) and nowhere in between [37, 43-45]. Although the southern part of the Australasian Tectonic Plate was located at latitude $60-65^{\circ} \mathrm{S}$ during the Late Cretaceous, palaeo-oxygen analyses of the sediments in the South Tasman Sea indicate a mean annual temperature of $19.5^{\circ} \mathrm{C}$ (Figure 3). At this latitude, the sun would shine throughout the year, with no long winter night [46]; the temperature differed by only a few degrees from winter to summer [29], thus favoring tall open-forest vegetation, similar to the structure of the vegetation inland from the coast of northern New South Wales.

Palynological studies showed that, from the mid-Miocene, the aridity of the continent increased progressively from north-western Australia, across inland Australia into south-eastern Australia [20, 22-25]. As the climate became drier in the Early Tertiary, the genus Eucalyptus (including the bloodwood now known as Corymbia) appears to have evolved as an overstorey to the Gondwanan heathland and 


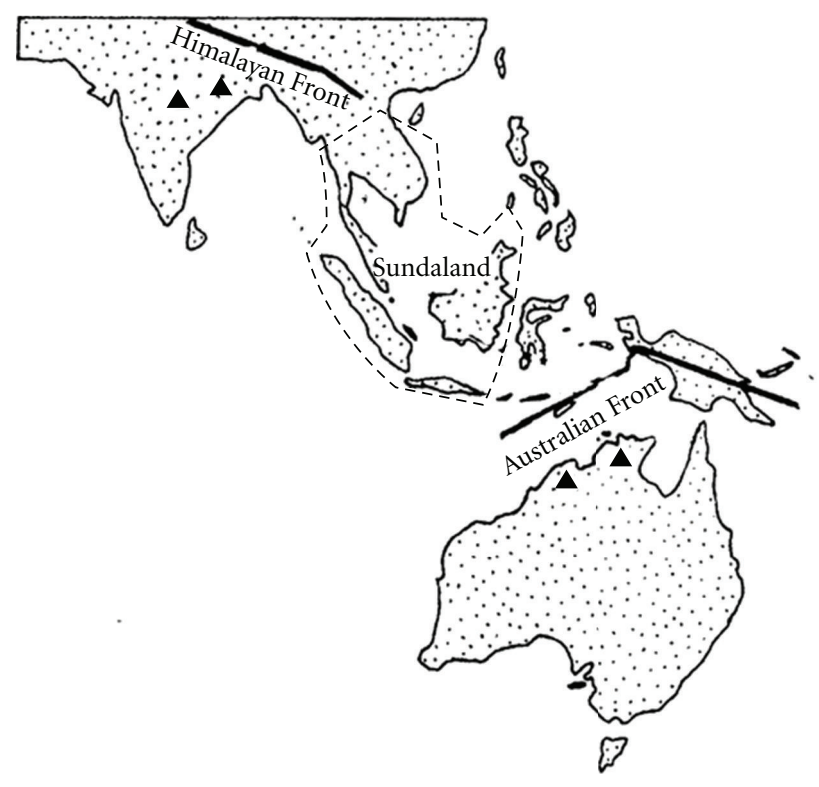

FIGURE 2: Some (14\%) of the flora that has been recorded on the sandstone outcrops $(\boldsymbol{\Delta})$ in northern Australia has also been found in the sandstone hills of eastern India ([37], see [5, Figure 5.8]). The Fronts of the Australian and Himalayan Tectonic Plates are shown by solid lines; the extent of the Sundaland Platelet is shown by a broken line.

grassland vegetation [32]. The original rainforest vegetation of the tropical north-which is linked with New Guinea [49] — and the temperate south survived in only a few perhumid sites. Some taxa of the Early Tertiary flora became separated by thousands of kilometres on either side of the continent [44]; the present-day floras of south-western and south-eastern Australia overlapped on Kangaroo Island and adjacent Peninsulas of South Australia [50].

During the Mid Miocene, a second period of laterisation occurred in south-eastern to central Queensland [51, 52] when a period of global warming of almost $5^{\circ} \mathrm{C}$ (Figure 3 ) was recorded in the surface water temperatures near-shore in north-eastern Australia [48]. A subtropical climate, with rainfall maintained high throughout the year, was necessary to produce the oscillating reducing and oxidizing conditions that resulted in the lateritic concretion stratum at the junction of the A and $\mathrm{B}$ horizons. This second period of lateritisation was apparently not produced in the cooler climate in southern New South Wales $[21,53]$.

Based on the isotopic signature of $\delta^{18} \mathrm{O}$ in kaolinitic soil profiles, Bird et al. [54] suggested that a rise in atmospheric carbon dioxide was associated with these weathering profiles during both the Late Cretaceous and the Mid Tertiary.

Later, as aridity increased in the centre of Australia during the Mid Tertiary-from the north-west to the southeast [25]-tropical rainforests were replaced by Acacia aneura shrublands and Triodia hummock grasslands. Under a monsoonal (summer-wet) climate, alumino-silicates were dissolved from the opal phytoliths that developed in the epidermal cells of grasses ([55, 56], [5, Page 312]), such as Triodia spp., that had become common in inland Australia.

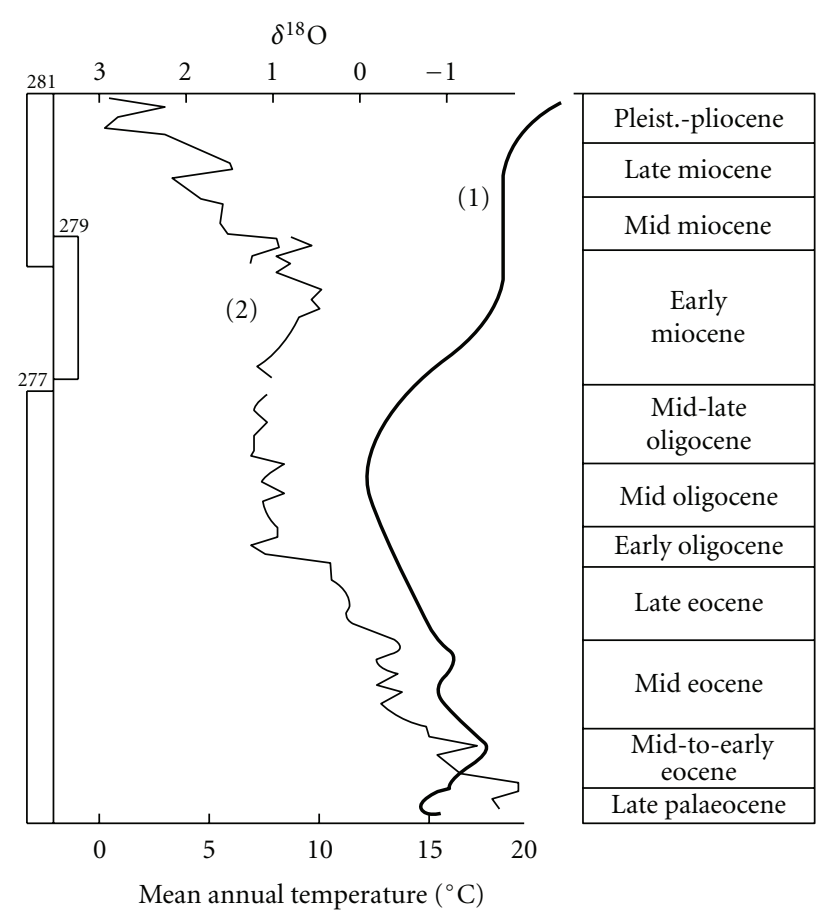

Figure 3: Variations in surface water temperatures during the Cainozoic: (1) in the near-shore, north-eastern Australian region (adapted from Feary et al. [47]) and (2) on the Campbell Plateau in the South Tasman Rise (after Shackleton and Kennett [48]).

Silcrete (termed "grey billy") was precipitated on the underlying rocks [51, 57-59]. Today, the distribution of silcrete in Central Australia [60] is essentially the same as that of Triodia hummock grassland [5, Page 114].

The Mid-Tertiary marine inundations in southern Australia, that submerged the Eucla Basin and the Murray Basin, and so forth, resulted in the deposition of a great depth of calcareous material, composed of foraminifera and molluscs, and so forth, [5, 61]. After the seas retreated, the soils that developed on this calcareous substrate experienced a continual accession of sea spray (cyclic salt). Depending on the degree of leaching, varying amounts of sodium ions became associated with the clay cations of these soils, thus producing a solonetzic B horizon. Both coastal and inland sand-dunes became mobile following devegetation during the arid cycles of the Quaternary. Vast sand-dune systems developed in southern Australia-on Eyre Peninsula, the Ninety-Mile Plain in the Upper South East District, and the Murray Mallee District-and extended eastward into Victoria as the Little and Big Deserts and the Sunset Country. The arid centre of the continent became a dust-bowl in which extensive dune systems resulted. The impacts of these geological events on southern Australian soils and vegetation were summarised by Dr. Crocker of the Waite Agricultural Research Institute and Prof. Wood of the Botany Department of the University of Adelaide [62, 63]. 


\section{Biodiversity in Arnhem Land}

The study of biodiversity in the Arnhem Land vegetation in Northern Australia was one of the aims of the botanist, Specht, on the 1948 American-Australian Scientific Expedition to Arnhem Land $[64,65]$.

(1) Over 200 woody species of plants growing on the sandstone hills and lateritic earths of Northern Australia have also been recorded in the sandstones of western Bengal and central India-and nowhere in between (Figure 2). Hooker of Kew-who had been on the Antarctic voyage of the Erebus and Terror, and afterwards studying the flora of Tasmaniareported this observation, based on Ferdinand von Mueller's collections on the Gregory Expedition to find Leichhardt, in his Introductory Essay to the Flora Tasmaniae [43]. Specht painstakingly searched for collection records of these plants between Northern Australia and India-without success [37, 45]. These species have been isolated since the breakup of Gondwanaland over 50 million years ago (Figure 2).

(2) Many species of plants recorded in the residual rainforests, eucalypt open-forests, wetlands and coastal vegetation of Arnhem Land are widely distributed across tropical and subtropical Australia.

(3) The flora of the sandstone hills and associated sandy outwash soils contain genera typical of the heathland species ( \pm overstorey eucalypts) that are common on the nutrient-poor soils of southern and eastern Australia.

Heathland Shrubs-Fabaceae (Bossiaea, Daviesia, Jacksonia); Myrtaceae (Asteromyrtus/Melaleuca, Calytrix); Poaceae (Triodia microstachya); Proteaceae (Banksia, Grevillea, Hakea, Persoonia); Santalaceae (Exocarpos); Sapindaceae (Dodonaea).

Heathland Understorey-Anthericaceae (Thysanotus); Campanulaceae (Wahlenbergia); Dilleniaceae (Hibbertia); Droseraceae (Drosera); Goodeniaceae (Goodenia); Haloragaceae (Haloragis); Loganiaceae (Mitrasacme); Phormiaceae (Dianella); Rutaceae (Boronia); Stackhousiaceae (Stackhousia); Stylidiaceae (Stylidium); Thymelaeaceae (Pimelea); Violaceae (Hybanthus); Xanthorrhoeaceae (Lomandra).

Two species of Leptocarpus in the Family Restionaceae, a characteristic component of heathland vegetation on nutrient-poor soils in both southern Australia and South Africa, flourish in wetlands at the base of sandstone hills. A species of Patersonia (Iridaceae), very similar to a species in south-west Western Australia, was collected by the geologist Herbert Basedow on the Mackay Expedition to Arnhem Land in 1928 [44]. Species of the semisucculent genus Calycopeplus (Euphorbiaceae) were recorded from Cape York Peninsula, in Arnhem Land and in southwest Western Australia [5, 44]. Species of the resurrection plant Borya (Xanthorrhoeaceae) have been recorded in northern Queensland, Arnhem Land, the Kimberley, and south-west Western Australia, with a species from a single peak in the northern Grampians, Victoria [5, 44].

(4) The species-richness (number of plant species per hectare) in every area of Eucalyptus tetrodonta openforest, that were collected near Darwin, on Groote Eylandt, on Bickerton Island and in north-eastern Arnhem Land, were almost identical [66] —also at Weipa in Cape York Peninsula [67].

(5) The species-richness (number of species per hectare) of both plants (in overstorey and understorey) and resident vertebrates (mammals, birds, snakes, amphibia. lizards) in each ecosystem throughout Australia is determined by the amount of solar energy converted yearly to carbohydrates by the foliage of the plant community [5, 68-71].

(6) Background atmospheric radiation (radon and thoron), maybe when supplemented by radiation from uranium ([5, pp. 69-70]; [72]), increases the "microendemism" of unicellular desmids that divide every few days. Extremely high numbers of unique taxa (136 taxa) were recorded in Red Lily Lagoon near Oenpelli [73] whereas about 10 different desmid taxa were recorded in pools in the sandstone hills nearby or in southern Australia [73, 74].

Phreatoicidean isopods also show "microendemism" in Arnhem Land with 1 or 2 unique taxa each with a small apparent range, maybe less than a kilometre [75]. South of Oenpelli, Buz Wilson found 3 species and in the North Jabiluka outlier there was as many as 11 species [75].

Plants and animals that have a long reproductive cycle do not appear to be affected by increased background radiation - at least in the Rum Jungle area (W. E. Bateman, pers. comm., 1952).

(7) In the Eucalyptus tetrodonta open-forest, wetlands, coastal dunes, and mangroves of the lowlandswhere physicochemical processes ensure the dynamic equilibrium of "structure, growth, and biodiversity" in the ecosystem - the chances of survival of any new species that may have evolved over the last 50 million years will be slim.

(8) About 20 new species of plants were collected in the crevices of the sandstone on the Arnhem Land Expedition [66] — not in the Eucalyptus tetrodonta open-forest, wetlands, coastal dunes, and mangroves of the lowlands.

\section{Major Plant Communities}

The plant communities that had been described in the many ecological surveys [76] made throughout the continent were collated under structural formations and their conservation status assessed [77].

As plant communities had been defined subjectively in most ecological surveys throughout Australia, the floristic 
TABLE 1: The conservation status of major TWINSPAN Floristic Groups that contain the majority of plants and resident animals in Australia [79].

\begin{tabular}{lccc}
\hline Formation/complex & No. of species analysed & Floristic groups number & Conservation reasonable \\
\hline Rainforest & 1418 & 70 & $70 \%$ \\
Monsoon rainforest (N.T.) & 559 & 16 & $31 \%$ \\
Dry scrub (SE Qld) & 475 & 29 & $26 \%$ \\
Eucalypt open forest & 276 & 237 & $49 \%$ \\
Eucalypt communities (SW W.A.) & 1761 & 31 & $64 \%$ \\
Heathland/scrub & 2071 & 83 & $53 \%$ \\
Alpine heath and grassland & 556 & 24 & $67 \%$ \\
Grassland & 1313 & 23 & $13 \%$ \\
Mallee (including SW W.A.) & 395 & 62 & $41 \%$ \\
Desert Acacia & 1229 & 104 & $17 \%$ \\
Hummock grassland & 303 & 10 & $30 \%$ \\
Chenopod shrubland & 410 & 19 & $26 \%$ \\
Forested wetland & 835 & 29 & $24 \%$ \\
Freshwater swamp & 139 & 24 & $25 \%$ \\
Coastal dune vegetation & 315 & 16 & $69 \%$ \\
Coastal wetland & 74 & 32 & $47 \%$ \\
Sclerophyll (heathy) understorey & 2581 & 21 & $34 \%$ \\
Savanna (grassy) understorey & 1313 & 39 & $11 \%$ \\
Hummock grass understorey & 303 & 20 & $35 \%$ \\
Humid \& arid wetland & 139 & 30 & $13 \%$ \\
\hline
\end{tabular}

data of each major plant community in each structural formation were collated in 16 data-banks for computer analysis by the classification program TWINSPAN [78]. The distributions of 345 TWINSPAN Floristic Groups, defined objectively, were plotted on every $30^{\prime}$ latitude $\times 30^{\prime}$ longitude grid-cell throughout the continent, and the conservation status of each TWINSPAN Floristic Group assessed (Table 1 after [79]).

\section{Seasonal Phenology}

The regular production-during the summer months-of new foliage and flowers in overstorey eucalypts of openforests and of mallee open-scrubs, in dominant shrubs of heathlands and in dominant species of tussock grasslands during the driest months in the Mediterranean-type climate of southern Australia [80-84], posed an ecological conundrum concerning the water relations of these species. Unlike the summer growth rhythm of the overstorey plants, understorey plants in all these plant communities initiated new foliage shoots and flower buds during springtimethe season of maximal available water [81, 85-89]. Rootlet growth, however, occurred in both overstorey and understorey species during the same season-spring - when litter decomposition was maximal $[80,90,91]$.

Year-long water balance studies on all these plant communities revealed that the horizontal coverage of all the leaves in the plant community-that is, the Total Foliage Projective Covers (FPCs) of the overstorey and understorey strata-was so adjusted to the aerodynamic fluxes in the atmosphere as it flows over and through the plant community that soil water was conserved during the wet winterspring season to be utilized during the dry summer season $[91,92]$.

Growth rhythms of foliage shoots and rootletssimilar to that of the heathlands of southern Australiawere observed in the overstorey and understorey strata of the fynbos (protead-ericad-restiad heathlands) in the Mediterranean-type climate of Cape Province, South Africa $[93,94]$. This disjunction in springtime rootlet production and summer shoot growth in overstorey species was thus apparent on the nutrient-poor soils in the fynbos of Cape Province as well as in heathlands, eucalypt open-forests, mallee open-scrubs and tussock grasslands on the nutrientpoor soils of southern Australia.

In contrast, both rootlet and foliage shoot growth occur in the same springtime season in the overstorey and understorey of the inland renosterveld-now a shrubland of Elytropappus rhinocerotis, with a former overstorey of Euclea, Olea, Pterocelastrus, Rhus, and Sideroxylon-on the more fertile soils of the Malmesbury Shales in Cape Province ([5, Page 298]; [93, 95]). On the medium-nutrient soils in the Mediterranean-type climates of southern California and southern France, Annual Shoot Growth of the chaparral and garrigue vegetation occurred during springtime — not during the dry summer season $[96,97]$.

The summer foliage-growth rhythm of the overstorey species in the Mediterranean-type climates of southern Australia and South Africa appears to be a heritage of the climatic conditions that existed when southern Australia and Africa were part of Gondwanaland 50 million years ago. 
Palaeo-oxygen studies [48] on the sea-floor deposits on the Campbell Plateau of the South Tasman Rise indicate that surface water temperature was then around $15-20^{\circ} \mathrm{C}$. As the Southern Ocean increased in latitude as the continental plate of Australia drifted northward at a rate of $53-70 \mathrm{~mm}$ per year $[98,99]$, the surface water temperatures became progressively cooler, reaching $0-5^{\circ} \mathrm{C}$ by the Plio-Pleistocene. Thus, the subtropical vegetation $[19,26,29,100]$ that flourished in southern Australia at the beginning of the Tertiary became stranded in the temperate climate of the present day.

Today, foliage shoot growth of the overstorey trees in subtropical eucalypt open-forests and rainforests occurs during springtime-the driest time of the year in southeastern Queensland-and again in autumn at a reduced rate of production [101-108]. Flower production follows the shoot growth phenology in subtropical eucalypt open-forests [83]. This subtropical growth rhythm-termed mesotherm [5] - is initiated when mean monthly air temperature rises above $15^{\circ} \mathrm{C}$, reaches a peak at $20^{\circ} \mathrm{C}$, and ceases by $25^{\circ} \mathrm{C}$ $[5,105,109]$.

The spring-autumn foliage growth rhythm of the mesotherm (subtropical) vegetation that dominated the southern Australian landscape in the Early Tertiary gradually shifted to a summer growth rhythm as the climate became cooler during the Cainozoic $[5,80]$. The temperature increment that is predicted to occur with Global Warming in the near future will induce a shift in the summer foliage growth rhythm of the overstorey plants in southern Australia back from summer to spring-a season during which Mediterranean-climate rains are far more favourable for growth. The microtherm understorey with a shoot growth rhythm ranging from $10-20^{\circ} \mathrm{C}$ with a peak at $15^{\circ} \mathrm{C}$ will then flourish during the winter temperatures $[5,80]$.

In north-eastern Australia, surface sea-water temperatures have increased by only about $5^{\circ} \mathrm{C}$ [47] during the last 50 million years as the Australasian Continental Plate has drifted northward from Antarctica. The macrotherm foliage growth rhythm, with mean monthly air temperatures ranging from $20-30^{\circ} \mathrm{C}$, of the Eucalyptus tetrodonta open-forest/woodland and the monsoonal rainforest residuals-from Cape York Peninsula, Queensland, across the Northern Territory to the Kimberley in Western Australia-has survived throughout the Tertiary $[5,45,109]$.

\section{Foliage Projective Cover}

An assessment of the foliage covers of overstorey ( $>2 \mathrm{~m}$ ) and understorey $(<2 \mathrm{~m})$ strata that have developed in the seasonally-droughted plant communities that cover most of Australia was recorded using upward and downward vertical cross-wire sighting tubes at $50 \mathrm{~cm}$ intervals along five to ten randomly located $50 \mathrm{~m}$ transects. The mean values of these transect records defined the Foliage Projective Covers (FPC) in the overstorey and understorey strata of the plant community.

Detailed studies of the Foliage Projective Covers (FPC) in overstorey $(\mathrm{o})$ and understorey $(\mathrm{u})$ strata in a range of TWINSPAN Floristic Groups reveal that the sum

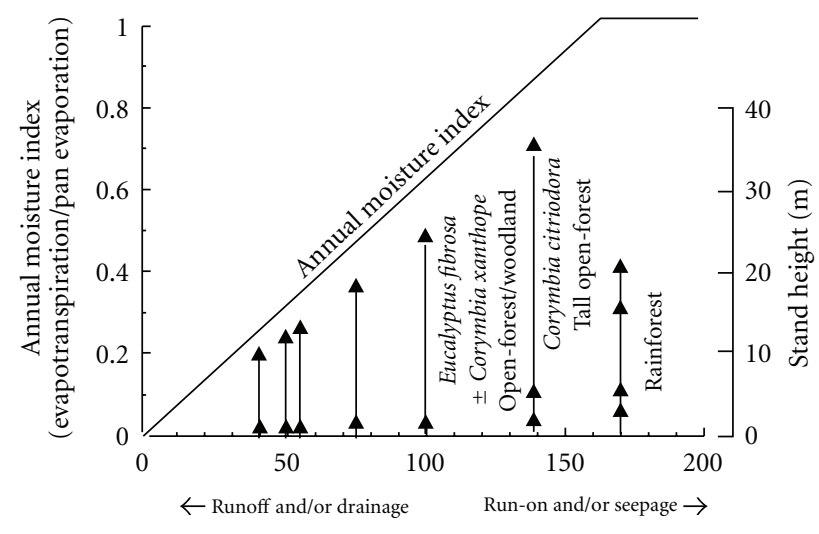

Annual precipitation retained in the soil profile (\%)

FIGURE 4: Vegetation on a soil catena on a serpentinite substrate in State Forest no. 114, Rockhampton-Marlborough region, Central Queensland $\left(23^{\circ} 06^{\prime} \mathrm{S}, 149^{\circ} 58^{\prime} \mathrm{E}\right)$ ([113], see [5, Figure 12.18]).

$\sum(\mathrm{FPCo}+\mathrm{FPCu})$ is related to the community-physiological constant, the Evaporative Coefficient [92] - the monthly ratio of actual to potential evapotranspiration per $\mathrm{mm}$ available soil water-from the arid to the humid climatic zones in tropical, subtropical, and temperate Australia [110]. $\sum(\mathrm{FPCo}+\mathrm{FPCu})$ remains essentially constant as Foliage Projective Cover in the overstorey changes during post-fire successions $[111,112]$ or decreases from the "climax plant formation" in edaphic and wetland continua $[111,113,114]$. Even the disjunct remnants of dry scrubs (rainforests) in a subhumid climate had the same $\sum(\mathrm{FPCo}+\mathrm{FPCu})$ as the series of eucalypt plant communities on the serpentinite soil catena in subtropical Central Queensland (Figure 4).

Field measurements of Foliage Projective Covers in the overstorey (when the grassy understorey is dry and brown) of over 150 timbered communities from the arid to the perhumid climatic zones of Queensland are closely correlated to the Normalised Difference Vegetation Index (NDVI) values that were recorded in 66 satellite observations at two-monthly intervals on 9 pixels (about $100 \mathrm{~m}^{2}$ ) [115]. Since 1988, Foliage Projective Cover of overstorey trees has been recorded in a Statewide Landcover and Trees Study (SLATS) on every pixel throughout the State [116].

\section{Foliage Structure}

The structure of a plant community influences the laminar flow of air over the overstorey strata (Figure 5). Irregularities (roughness) in open-structured plant communities induce turbulent air movement within the community whenever wind blows across the foliage canopy [117]. During the short growing season of foliage growth, aerodynamic fluxes (frictional, thermal, evaporative \pm atmospheric salinity) in the atmosphere as it flows over and through a plant community determine (1) the combined Foliage Projective Covers in overstorey and understorey strata- $\sum$ (FPCo + $\mathrm{FPCu}$ - and (2) the ratio of structural to cytoplasmic cells 


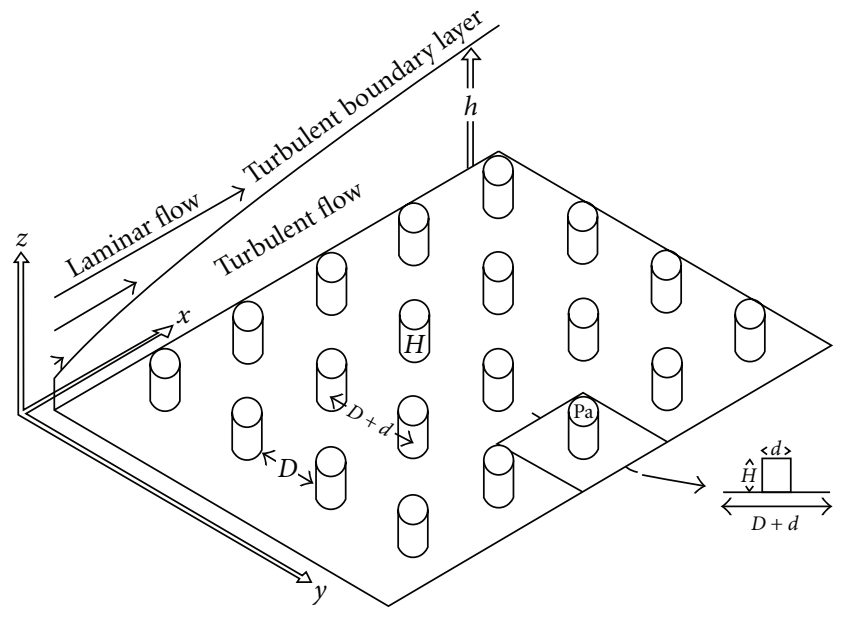

(a)

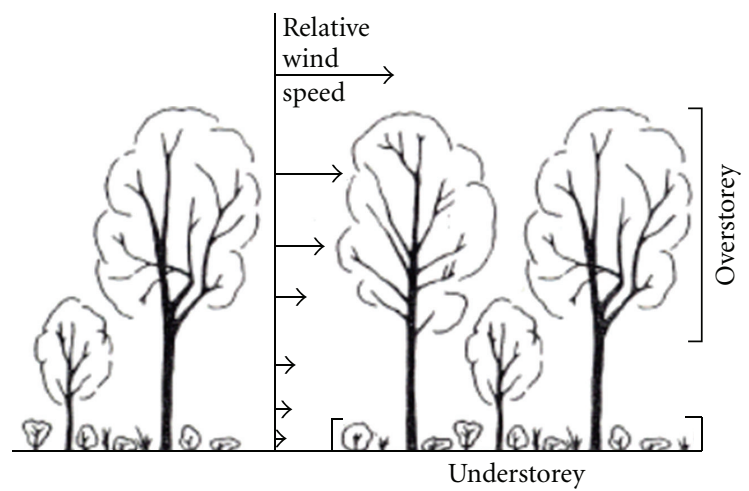

(b)

Figure 5: (a) A wind tunnel experiment to assess the effect of surface roughness on the laminar flow of air over an array of small cylinders of different diameter $(d)$ and height $(h)$ ([118]; see[5, Figure 11.9]). (b) A sketch showing the variation in resistance of overstorey and understorey strata in a plant community to the laminar flow of wind ([109]; see [5, Figure 11.9]).

in each leaf and, thus, the Leaf Area and Leaf Specific Weight of each developing leaf.

At the same time during this short growing-season, soil water and soil nutrients available within the rooting zone influence the number of leaves produced on each vertical foliage shoots-but not the lateral growth (FPC) and leaf attributes of each plant [5]. Thus, although $\sum$ (FPCo + $\mathrm{FPCu}$ ) remains constant, vertical height of each life-form may vary in each structural formation, such as in closedforest (FPC 100-70\%), in open-forest (FPC 70-30\%), in woodland (FPC 30-10\%), and in open-woodland (FPC < $10 \%)$.

As the number of old leaves that abscise from vertical foliage shoots is generally the same as the number of new leaves produced on each vertical foliage shoot during the short season of growth, both the Annual Shoot Growth (dry weight of leaves per hectare) and Leaf Area Index (area of leaves per hectare) can be estimated in evergreen plant communities by measuring the following.
(1) Area and dry weight of leaf litter that falls into randomly distributed litter trays throughout the year.

(2) Area and dry weight of mature leaves per vertical foliage shoot - of leaves produced during the current year and the one or two leaves remaining from the previous year.

The canopy structure that is produced in the overstorey stratum of a plant community during the short season of foliage growth determines the net photosynthetic potential of the plant community throughout the year $[68,119]$.

Cyclical changes [120] of regeneration, development, maturation, and senescence that may be observed in a plant community during its life cycle-often truncated by fire in the Australian fire-tolerant vegetation [121]—must be examined in all stages of a soil-vegetation chronosequence. During these cyclical changes, the sum of overstorey and understorey Foliage Projective Covers has been shown to remain a constant [5]. Net photosynthesis of the whole plant community (per hectare) thus remains roughly constant throughout the life-cycle. The living cells of stems and roots in the plant community grow continually-thus, community respiration and carbon dioxide output increase dramatically from the regeneration to the maturation phase. Respiration (per hectare) of dependent consumers and decomposers increases simultaneously with available food sources in stems and roots during the regeneration phase. The senescence phase in a plant community will be associated with degeneration of the overstorey and regeneration of the understorey$\sum(\mathrm{FPCo}+\mathrm{FPCu})$, the sum of overstorey and understorey Foliage Projective Covers will remain constant. During the senescent phase of an ecosystem, respiration will increase in degenerating tissues of the overstorey and associated consumers and decomposers-thus more carbon dioxide is released from "old-growth forests."

\section{Alpha Biodiversity}

Alpha Biodiversity of plant communities can be assessed by recording the increase in species richness to an asymptotic value as the area of the quadrat increased in size-the species-area curve [122-124].

Most open-structured plant communities in Australia approach a maximum value of species richness in an area of one hectare. A hectare of vegetation is essentially the same as that examined in the relevé phyto-écologue used by BraunBlanquet [125] and Long [126] in the survey of vegetation around the Mediterranean Basin. Vegetation in the CSIRO survey of the land systems in northern Australia was similarly recorded on areas of about one hectare $[127,128]$.

The species richness of dense stands of subtropical rainforest approaches a maximum only when the sample area is over 100 hectares $[5,129,130]$.

The climatic range from the monsoonal climate in the north to the Mediterranean-type climate in the south makes the continent of Australia ideal for the study of the structure, growth, and biodiversity of ecosystems. The interrelationships of the Alpha Biodiversity of plants and 
animals were presented in the Mediterranean Data Source Book [131] and at the MEDECOS VI conference on plantanimal interactions [132].

Aerodynamic fluxes (frictional, thermal, evaporative) exert the major control on the development of Foliage Projective Covers (FPCs) and leaf attributes (Leaf Area, Leaf Specific Weight, and Internode Length) in both the overstorey and understorey strata of a plant community [68, 94, 133-135]. The area of land covered by foliage in these two strata is thus determined, together with the photosynthetic potentials of all life forms. The annual vertical growth (biomass per hectare) of all foliage shoots is influenced by the ambient temperature, soil water, and soil nutrients available during the short growing-season in each stratum of a plant community.

The preponderance of nutrient-poor and mediumnutrient soils on the Australian continent has enabled the survival and evolution of the hardy Gondwanan vegetationcool temperate to tropical rainforest species; sclerophyll (heathy) and savanna (grassy) understoreys ( \pm eucalypts); arid zone chenopods and desert Acacias_-all of which have remarkable ecophysiological attributes to survive in this harsh environment where bush-fires have been common for at least 50 million years [5, 136]. Alpha Biodiversity (the number of species per hectare) in the overstorey of a plant community is correlated with the annual growth (biomass per hectare) of all foliage shoots in this stratum $[119,137,138]$. Alpha Biodiversity in the understorey is strongly affected by the degree of shading produced by the overstorey $[69,112,113,139,140]$.

The fixation of solar energy as biomass in foliage shoots [141-143] provides the major source of high-energy carbohydrates for the nonphotosynthetic parts of a plant community and dependant consumers and decomposers. It is not surprising that the Alpha Biodiversity of producers, consumers, and decomposers in any ecosystem may be correlated (Figures 6 and 7, after [5, 70, 114, 129, 131, 132, 144-147]).

The species richness of decomposers — such as soil and litter invertebrates - may also be correlated with the food resource provided by the annual fall of litter [148-150].

As aerodynamic fluxes have an abrasive (desiccation) effect on the edges of isolated stands of vegetation, an area of over 100 hectares of subtropical rainforest appears to be necessary to minimise these fluxes on community structure and biodiversity of plants and resident birds $[5,129,130]$.

The horizontal spread of foliage - that is $\sum$ (FPCo + $\mathrm{FPCu}$ _-and leaf morphological attributes of plants from canopy to ground level in a plant community are influenced by aerodynamic fluxes during the short growing-season when new foliage is produced. At the same time, available soil water and nutrients determine the number of leaves that are formed on each vertical foliage shoot. Thus, the annual fixation of solar energy (as biomass per hectare) is determined; the number of species of producers, consumers, and decomposers that survive in each ecosystem depends on this energy supply.

\section{Gamma Biodiversity}

The high Gamma Biodiversity (number of species per region) found in the rainforest of north-east Queensland, in the vegetation on the Hawkesbury Sandstone near Sydney, and in the heathland vegetation of south-west Western Australia [151], probably evolved in well-watered pockets during extreme drought periods in the Tertiary (Figure 3). When the vegetation expanded after a favorable climate was restored, the species richness (Alpha Biodiversity, the number of species per hectare) was restored [5, pp. 317-338]. Alpha Biodiversity (number of plants per hectare) cannot be restored on the starkly eroded Arnhem Land sandstones in the monsoonal climate of Northern Australia.

\section{Pollution and Biodiversity}

The biodiversity of the flora and fauna in the openstructured plant communities of much of Australia has survived over 50 million years on soils rich in kaolinite that fixes phosphates in an unavailable form within its clay lattice. Today, these ecosystems are under threat from phosphate pollution $[4,69,84,152-156]$. As the native vegetation degrades exposing more of the soil to solar radiation, soil nitrate ions instead of the normal ammonium ions are produced in the decomposition of organic matter; exotic plants with much thinner leaves, high in nitrate reductase enzyme are then able to invade $[8,157,158]$. A sizable buffer zone, large enough to reduce phosphate pollution and the invasion of exotic plants, must surround each conservation reserve to ensure the survival of these ecosystems [159]; the impact of phosphorus pollution in litter and other debris along pathways must be reduced and counteracted $[5,155$, 160].

Atmospheric pollution, such as fluoride released from aluminium smelters, has also been shown to affect the growth and survival of species of eucalypts in the Subgenera Blakella and Corymbia, but has little effect on the Subgenus Symphyomyrtus in Central Queensland [161]. As the first two Subgenera are prominent in tropical ecosystems where species belonging to the Subgenus Symphyomyrtus also occur, fluoride pollution may ultimately reduce the species richness of the overstorey trees.

In the 1950s, the exploitation of uranium ores in the Northern Territory posed the possibility that radiation may affect the biodiversity of plants and animals on or near the deposits. No evidence of any obvious change could be detected in eucalypt diversity on these sites (W. E. Bateman, Forestry and Timber Bureau, pers. comm., 1952). Research at the Atomic Energy Laboratories at Chalk River, Ontario, Canada, clearly demonstrated that any radiation, above or below background, when exposed to trout sperm could have an effect on the number of eye malformations in the embryos $[72,162]$. Thus, it is possible that any unicellular organism, with a very short life-cycle of a few days, may show genetic variation when exposed to radiation-for example, the remarkable increase in diversity of desmid algae from about 10 taxa in pools associated with the sandstone hills throughout the Top End to 136 taxa in Red Lily Lagoon 


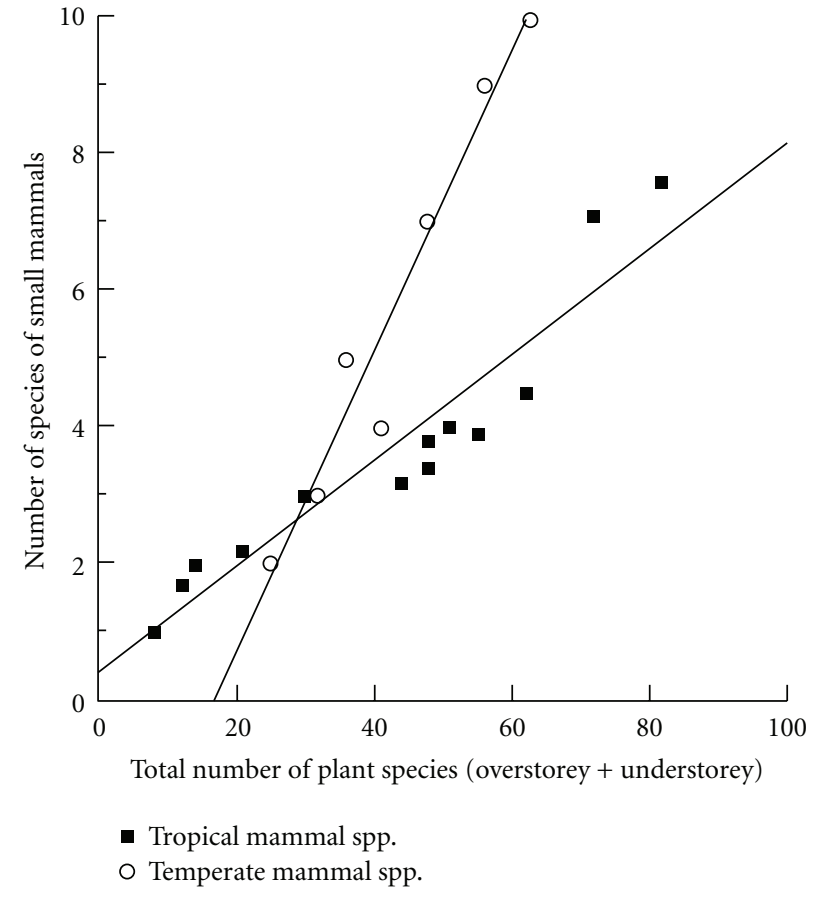

(a)

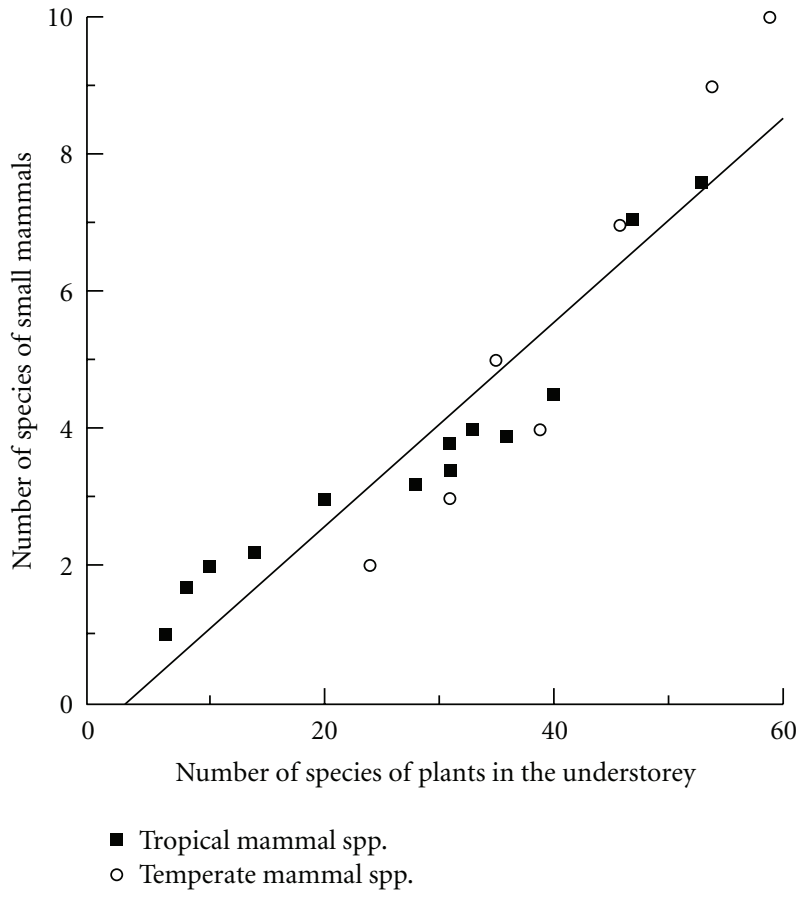

(b)

FIGURE 6: Number of small mammals recorded in plant communities in both southern and northern Australia is linearly correlated with (a) the total number of species of vascular plants in each plant community and (b) the number of plant species in the understorey [5, Figure 17.14].

near Oenpelli $[5,73,163]$. Small multicellular phreatoicidean isopods also show "microendemism" in Northern Australia with 1 or 2 unique taxa each with a small apparent range, maybe less than a kilometer; in contrast, 3 species were found in pools south of Oenpelli while 11 species were recorded in the North Jabiluka outlier [75].

\section{Global Warming and Biodiversity}

Since the Industrial Revolution, the level of carbon dioxide in the atmosphere has steadily increased to about $450 \mathrm{ppm}$ due to the burning of fossil fuels. Much of the black-body radiation reradiated from the surface of the Earth is trapped by these gases, thus gradually increasing the temperature in the atmosphere-the "greenhouse effect" ([5, Page 197]; [164]). The level of carbon dioxide in the atmosphere is now so high that Global Warming is inevitable-as had occurred during the Late Cretaceous and the Mid Tertiary (Figure 3).

An increase in atmospheric temperature of $2-5^{\circ} \mathrm{C}$ is predicted throughout the world; an increase of almost $1^{\circ} \mathrm{C}$ has been recorded over the last decade. A southerly shift of the "Polar Front" [165] will probably reduce wind speeds throughout the continent. As in the past, these changes in aerodynamic fluxes (frictional, thermal, evaporative) as the atmosphere flows over and through a plant community during the short period of seasonal foliage-growth will have a profound effect on native terrestrial ecosystems as well as on agriculture, forestry, horticulture, and rangeland land-use.
Although the annual growth of vertical foliage shoots in the plant communities may be increased by higher carbon dioxide, soil water, and increased air temperature, aerodynamic fluxes (frictional, thermal and evaporative) will cause a reduction in the overstorey and understorey foliage covers - therefore, tall open-forest $\rightarrow$ open-forest $\rightarrow$ woodland $\rightarrow$ open-woodland $\rightarrow$ tall shrubland $\rightarrow$ low shrubland. At the same time, higher air temperatures would increase respiration in stems and roots, also in consumers and decomposers - with respiration rates doubling with every $10^{\circ} \mathrm{C}$ increase in temperature; standing biomass (per hectare) in the plant communities would be reduced ([5, pp. 199-230]; [166, 167]).

Although there may be an increase in the number of leaves that are produced on vertical foliage shoots during the short season of shoot growth, the sum of the Foliage Projective Covers in overstorey and understorey strata-that is $\sum$ (FPCo + FPCu -will be reduced by Global Warming. The interception of solar radiation by the plant community will be reduced, thus reducing net photosynthetic fixation (per hectare per annum). Alpha Biodiversity of species of both plants and resident vertebrates in each ecosystem is threatened.

\section{Conclusions}

The scientific study of community-physiological processes that determine structure, growth, and biodiversity of 


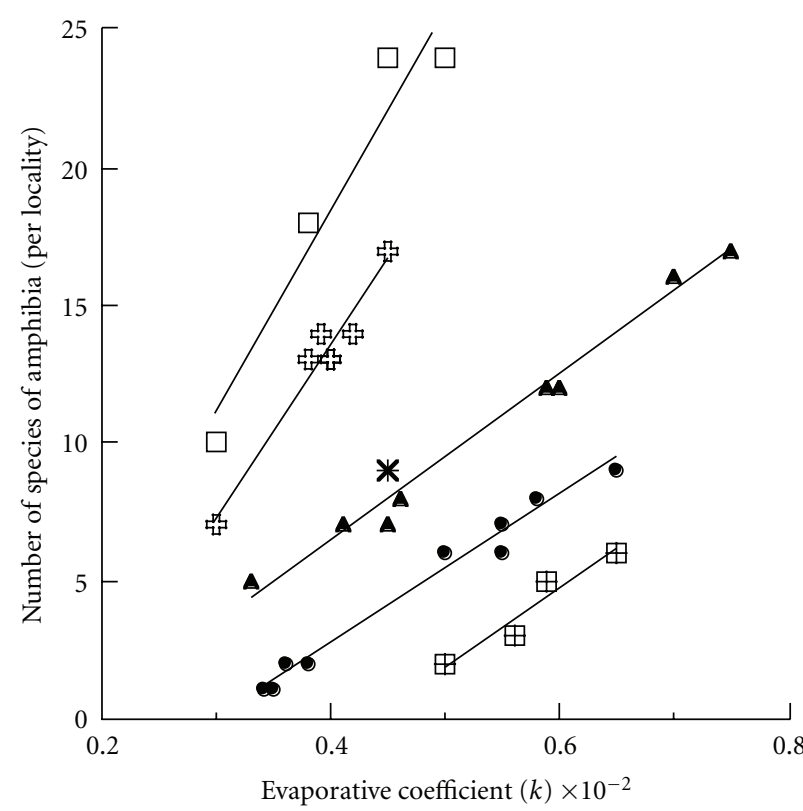

(a)

A South-east Australia
(medium-nutrient)
- South-west Australia
(nutrient-poor)
$\boxplus \begin{aligned} & \text { South Australia } \\ & \text { (extremely nutrient-poor) }\end{aligned}$

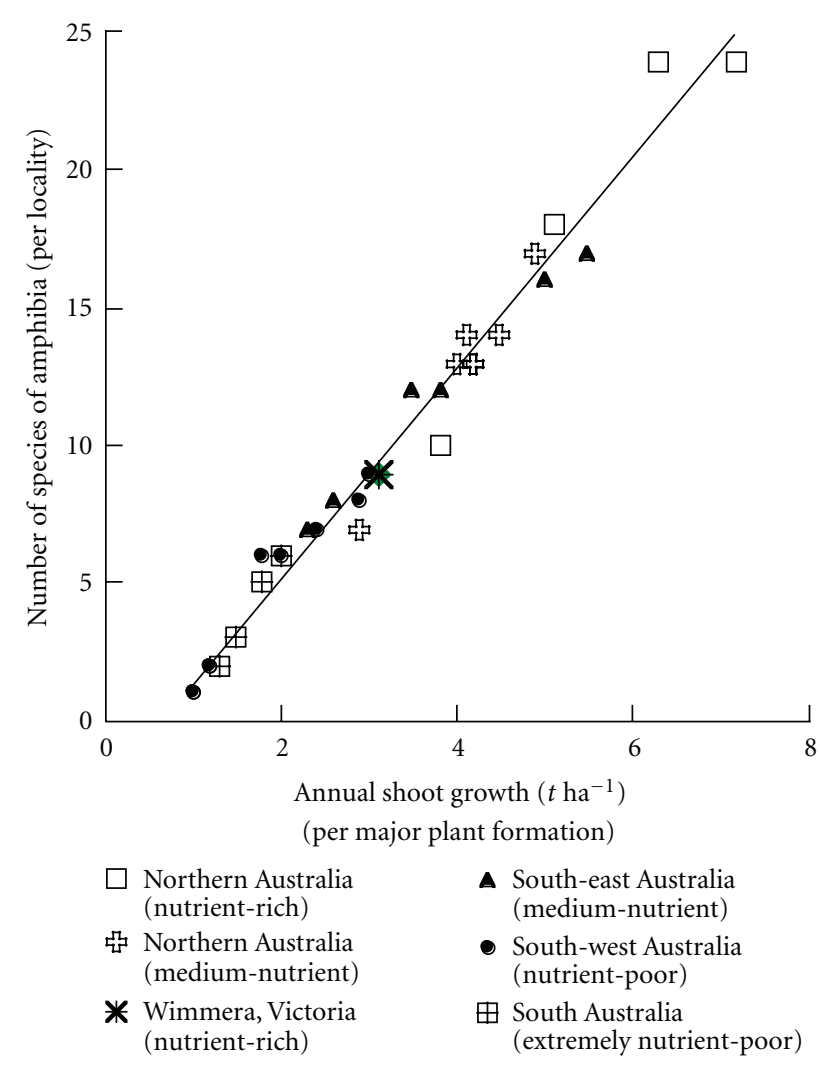

(b)

Figure 7: Number $(N)$ of species of amphibians in nutrient-rich, medium-nutrient, nutrient-poor, and extremely nutrient-poor habitats in northern and southern Australia, plotted against the Evaporative Coefficient $(k)$ of the sampling locality (a), and plotted against the Annual Shoot Growth of the major plant formation at the sampling site (b)—(after [147]).

plant communities (with associated consumers and decomposers) has been developed since the 1950s. Three major community-physiological processes need further research to understand the possible effects of Global Warming and pollution on Australian ecosystems.

(1) The sum of Foliage Projective Covers of the overstorey and understorey strata is a constant-in space and time-for each climatic region. This constant appears to be determined by aerodynamic fluxes (frictional, thermal, evaporative) in the atmosphere as it flows over and through a plant community during the short period of foliage shoot growth.

(2) The species richness (number of species per unit area) of overstorey and understorey strata of a plant community (and associated resident vertebrates) is correlated with Leaf Area Index (per hectare) and thus with the amount of solar energy fixed annually by the overstorey canopy.

(3) The evolution of new species of plants appears to be rare in terrestrial ecosystems that have survived in Northern Australia for over 50 million years. In contrast, many taxa of unicellular algae and small isopods have evolved in permanent freshwater lagoons that may have been exposed to increased background radiation.

\section{Acknowledgments}

The study of the physicochemical processes that determine the structure, growth, and biodiversity of plant communities (with associated consumers and decomposers) was fostered in the University of Adelaide during the 1940s. These researches were pursued under the auspices of the UNESCO Arid Zone Research Program, International Biological Program (IBP), Sections PT Productivity, PP Physiological Processes and CT Conservation of Terrestrial Ecosystems, the IBP Biome Studies Program, especially MEDECOS and TROPECOS, and the International Geosphere-Biosphere Program (IGBP) to understand the effects of global warming on terrestrial ecosystems.

\section{References}

[1] R. L. Specht, "Development of ecosystem research," International Scholarly Research Network ISRN Ecology, vol. 2011, Article ID 897578, 20 pages, 2011.

[2] A. G. Tansley, "The use and abuse of vegetational concepts and terms," Ecology, vol. 16, no. 3, pp. 284-307, 1935. 
[3] R. L. Crocker, "Soil genesis and the pedogenic factors," The Quarterly Review of Biology, vol. 27, no. 2, pp. 139-168, 1952.

[4] R. L. Specht, "Phosphorus toxicity and pollution: a threat to our Gondwanan heritage," Ecological Management \& Restoration, vol. 2, no. 3, pp. 228-230, 2001.

[5] R. L. Specht and A. Specht, Australian Plant Communities. Dynamics of Structure, Growth and Biodiversity, Oxford University Press, Melbourne, Australia, 1999.

[6] R. L. Specht and P. W. Rundel, "Sclerophylly and foliar nutrient status of mediterranean-climate plant communities in southern Australia," Australian Journal of Botany, vol. 38, no. 5, pp. 459-474, 1990.

[7] R. L. Specht and A. Specht, "The ratio of foliar nitrogen to foliar phosphorus: a determinant of leaf attributes and height in life-forms of subtropical and tropical plant communities," Australian Journal of Botany, vol. 58, no. 7, pp. 527-538, 2010.

[8] G. R. Stewart, C. A. Gracia, E. E. Hegarty, and R. L. Specht, "Nitrate reductase activity and chlorophyll content in sun leaves of subtropical Australian closed-forest (rainforest) and open-forest communities," Oecologia, vol. 82, no. 4, pp. 544551, 1990.

[9] J. A. Prescott and R. L. Pendleton, "Laterite and lateritic soils," Commonwealth Bureau of Soil Science \& Technology Communication, no. 47, 1952.

[10] J. C. Menaut, R. Barbault, P. Lavelle, and M. Lepage, "African savannas: biological systems of humification and mineralization," in Ecology and Management of the World's Savannas, J. C. Tothill and J. J. Mott, Eds., pp. 14-33, Australian Academy of Science, Canberra, Australia, 1985.

[11] K. H. Northcote et al., Atlas of Australian Soils, Sheets 1-10, C.S.I.R.O. (Aust.) \& Melbourne University Press, Melbourne, Australia, 1960-1968.

[12] A. G. Smith and J. C. Briden, Mesozoic and Caenozoic Palaeocontinental Maps, Cambridge University Press, Cambridge, UK, 1977.

[13] I. C. Cookson, "Pollen content of Tertiary deposits," Australian Journal of Science, vol. 7, pp. 149-150, 1945.

[14] I. C. Cookson, "Pollens of Nothofagus Blume from Tertiary deposits in Australia," Proceedings of the Linnean Society of New South Wales, vol. 71, pp. 49-63, 1946.

[15] I. C. Cookson, "Identification of Tertiary pollen grains with those of New Guinea and New Caledonian beeches," Nature, vol. 170, no. 4316, p. 127, 1952.

[16] I. C. Cookson, "Fossil pollen grains of Nothofagus from Australia," Proceedings of the Royal Society of Victoria, vol. 71, pp. 25-39, 1959.

[17] H. A. Martin, "The Tertiary stratigraphy and palynology of the Murray Basin in New South Wales. 1. The Hay-BalranaldWakool Districts," Journal and Proceedings of the Royal Society of New South Wales, vol. 110, pp. 41-47, 1977.

[18] H. A. Martin, "Evolution of the Australian flora and vegetation through the Tertiary: evidence from pollen," Alcheringa, vol. 2, no. 3, pp. 181-202, 1978.

[19] H. A. Martin, "The Tertiary flora," in Ecological Biogeography of Australia, A. Keast, Ed., pp. 391-406, Junk, The Hague, The Netherlands, 1981.

[20] H. A. Martin, "The Cainozoic history of the vegetation and climate of the Lachlan River Region, New South Wales," Proceedings of the Linnean Society of New South Wales, vol. 116, pp. 3-18, 1987.

[21] H. A. Martin, "Tertiary stratigraphic palynology and palaeoclimate of the inland river systems of New South Wales," in The Cainozoic in Australia: A Re-appraisal of the Evidence,
M. A. J. Williams, P. De Deckker, and A. P. Kershaw, Eds., No. 18, pp. 181-194, Geological Society of Australia, 1991.

[22] H. A. Martin, "The use of ecological tolerances for the reconstruction of Tertiary palaeoclimates," Australian Journal of Botany, vol. 45, no. 3, pp. 475-492, 1997.

[23] H. A. Martin, "Tertiary climatic evolution and the development of aridity in Australia," Proceedings of the Linnean Society of New South Wales, vol. 1998, no. 119, pp. 115-136, 1998.

[24] H. A. Martin, "Late Cretaceous-Cainozoic palynology of the Poonarunna no. 1 well, Central Australia," Transactions of the Royal Society of South Australia, vol. 122, no. 3-4, pp. 89-138, 1998.

[25] H. A. Martin, "Cenozoic climatic change and the development of the arid vegetation in Australia," Journal of Arid Environments, vol. 66, no. 3, pp. 533-563, 2006.

[26] M. E. Dettmann, "The Cretaceous flora," in Ecological Biogeography of Australia, A. Keast, Ed., pp. 355-375, Junk, The Hague, The Netherlands, 1981.

[27] D. C. Christophel, "Tertiary megafossil floras of Australia as indicators of floristic associations and palaeoclimate," in Ecological Biogeography of Australia, A. Keast, Ed., pp. 377390, Junk, The Hague, The Netherlands, 1981.

[28] M. E. Dettmann and D. M. Jarzen, "Pollen evidence for Late Cretaceous differentiation of Proteaceae in southern polar forests," Canadian Journal of Botany, vol. 69, no. 4, pp. 901906, 1991.

[29] R. L. Specht, M. E. Dettmann, and D. M. Jarzen, "Community associations and structure in the Late Cretaceous vegetation of southeast Australasia and Antarctica," Palaeogeography, Palaeoclimatology, Palaeoecology, vol. 94, no. 1-4, pp. 283-309, 1992.

[30] L. A. S. Johnson and B. G. Briggs, "Three old southern families-Myrtaceae, Proteaceae and Restionaceae," in Ecological Biogeography of Australia, A. Keast, Ed., pp. 472-469, Junk, The Hague, The Netherlands, 1981.

[31] H. T. Clifford and B. K. Simon, "The biogeography of Australian grasses," in Ecological Biogeography of Australia, A. Keast, Ed., pp. 537-554, Junk, The Hague, The Netherlands, 1981.

[32] H. A. Martin and P. A. Gadek, "Identification of Eucalyptus spathulata pollen and its presence in the fossil record," Memoirs of the Association of Australian Palaeontology, vol. 5, pp. 311-327, 1988.

[33] M. Pole, "Early Miocene floras from central Otago, New Zealand," Journal of the Royal Society of New Zealand, vol. 19, no. 2, pp. 121-125, 1989.

[34] M. Pole, "Early Miocene flora of the Manuherikia Group, New Zealand. 7. Myrtaceae, including Eucalyptus," Journal of the Royal Society of New Zealand, vol. 23, no. 4, pp. 313-328, 1993.

[35] R. S. Hill, "The history of selected Australian taxa," in History of Australian Vegetation: Cretaceous to Recent, R. S. Hill, Ed., pp. 390-419, Cambridge University Press, Cambridge, UK, 1994.

[36] M. E. Dettmann, D. T. Pocknall, E. J. Romero, and Maria del Carmen Zamaloa, Nothofagidites Erdtman ex Potonié, 1960: a catalogue of species with notes on the palaeographic distribution of Nothofagus Bl. (Southern Beech), Paleontological Bulletin No. 60, New Zealand Geological Survey, Lower Hutt, New Zealand, 1990.

[37] R. L. Specht, "Geographical relationships of the flora of Arnhem Land," in Botany and Plant Ecology, R. L. Specht and 
and C. P. Mountford, Eds., vol. 3 of Records of the AmericanAustralian Scientific Expedition to Arnhem Land, pp. 415-478, Melbourne University Press, Melbourne, Australia, 1958.

[38] N. T. Burbidge, "The phytogeography of the Australian region," Australian Journal of Botany, vol. 8, no. 2, pp. 75$211,1960$.

[39] H. T. Clifford and L. Watson, Identifying Grasses: Data, Methods and Illustrations, Queensland University Press, St Lucia, Australia, 1977.

[40] P. W. Hattersley, "The distribution of $\mathrm{C}_{3}$ and $\mathrm{C}_{4}$ grasses in Australia in relation to climate," Oecologia, vol. 57, no. 1-2, pp. 113-128, 1983.

[41] P. W. Hattersley and L. Watson, "Anatomical parameters for predicting photosynthetic pathways of grass leaves: the "maximal lateral cell count" and the "maximal cell distance count"”, Phytomorphology, vol. 25, pp. 325-333, 1975.

[42] P. W. Hattersley and L. Watson, " $\mathrm{C}_{4}$ grasses: an anatomical criterion for distinguishing between NADP-Malic enzyme species and PCK or NAD-Malic enzyme species," Australian Journal of Botany, vol. 24, no. 2, pp. 297-308, 1976.

[43] J. D. Hooker, "On the flora of Australia, being part of an Introductory Essay to Flora Tasmaniae," in The Botany of the Antarctic Voyage of H. M. Discovery Ships Erebus and Terror, in the Years 1839-1843, vol. 1, Part III, pp. 27-128, UK, 1860.

[44] R. L. Specht, "Major vegetation formations in Australia," in Ecological Biogeography of Australia, A. Keast, Ed., pp. 163297, Junk, The Hague, The Netherlands, 1981.

[45] R. L. Specht, "Origin and evolution of terrestrial plant communities in the wet-dry tropics of Australia," Proceedings of the Ecological Society of Australia, vol. 15, pp. 19-30, 1988.

[46] F. Loewe, "The intake of solar radiation by slopes, with cloudless sky," Commonwealth of Australia Bureau of Meteorology Bulletin, no. 45, 1962.

[47] D. A. Feary, P. J. Davies, C. J. Pigram, and P. A. Symonds, "Climatic evolution and control on carbonate deposition in northeast Australia," Palaeogeography, Palaeoclimatology, Palaeoecology, vol. 89, no. 4, pp. 341-361, 1991.

[48] N. J. Shackleton and J. P. Kennett, "Palaeotemperature history of the Cenozoic and the initiation of Antarctic glaciation: oxygen and carbon isotope analyses in DSDP sites 277, 279, 281," in Initial Reports of the Deep Sea Drilling Project, 29, pp. 743-755, United States Government Printing Office, Washington, DC, USA, 1975.

[49] D. Walker, Ed., Bridge and Barrier: The Natural and Cultural History of Torres Strait, Australian National University Press, Canberra, Australia, 1972.

[50] J. G. Wood, "An analysis of the vegetation of Kangaroo Island and the adjacent peninsulas," Transactions of the Royal Society of South Australia, vol. 54, pp. 105-139, 1930.

[51] G. G. Beckmann, "Development of soil landscapes," in Soils. An Australian Viewpoint, Sponsored by C.S.I.R.O., Division of Soils, pp. 163-169, CSIRO Publishing, Melbourne, Australia, 1983.

[52] W. F. Willmott, "Rocks and Landscapes of the National Parks of Southern Queensland," Geological Society of Australia, Queensland Division, Brisbane, Australia, 2004.

[53] H. C. T. Stace Jr., G. D. Hubble, R. Brewer et al., A Handbook of Australian Soils, Rellim Technical Publications, Glenside, Australia, 1968.

[54] M. L Bird, B. Fyfe, A. Chivas, and F. Longstaff, "Deep weathering at extra-tropical latitudes: a response to increased atmospheric $\mathrm{CO}_{2}$," in Proceedings of the International Conference, Soils and the Greenhouse Effect, A. F. Bouwman, Ed., pp. 383-389, John Wiley \& Sons, Chichester, UK, 1990.

[55] G. Baker, "Opal phytoliths in some Victorian soils and 'red rain' residues," Australian Journal of Botany, vol. 7, no. 1, pp. 64-87, 1959.

[56] G. Baker, "A contrast in the opal phytolith assemblages in two Victorian soils," Australian Journal of Botany, vol. 7, no. 1, pp. 88-96, 1959.

[57] C. G. Stephens, "Laterite and silcrete in Australia: a study of the genetic relationships of laterite and silcrete and their companion materials, and their collective significance in the formation of the weathered mantle, soils, relief and drainage of the Australian continent," Geoderma, vol. 5, no. 1, pp. 5$52,1971$.

[58] T. Langford-Smith, Ed., Silcrete in Australia, Department of Geography, University of New England, Armidale, Australia, 1978.

[59] G. H. Dury, G. M. Habermann et al., "Australian silcretes and Northern Hemisphere correlatives," in Silcrete in Australia, T. Langford-Smith, Ed., pp. 223-259, Department of Geography, University of New England, Armidale, Australia, 1978.

[60] G. D. Hubble, R. F. Isbell, and K. H. Northcote, "Features of Australian soils," in Soils. An Australian Viewpoint, Sponsored by C.S.I.R.O., Division of Soils, pp. 17-47, CSIRO Publishing, Melbourne, Australia, 1983.

[61] R. L. Specht, The Vegetation of South Australia, Government Printer, Adelaide, Australia, 1972.

[62] R. L. Crocker, Post-Miocene Climatic and Geologic History and its Significance in Relation to the Genesis of the Major Soil Types of South Australia, Bulletin No. 193, Council of Scientific and Industrial Research, Melbourne, Australia, 1946.

[63] R. L. Crocker and J. G. Wood, "Some historical influences on the development of the South Australian vegetation communities and their bearing on concepts and classification in ecology," Transactions of the Royal Society of South Australia, vol. 71, pp. 91-136, 1947.

[64] R. L. Specht and C. P. Mountford, Eds., Botany and Plant Ecology, vol. 3 of Records of the American-Australian Scientific Expedition to Arnhem Land, Melbourne University Press, Melbourne, Australia, 1958.

[65] M. Thomas and M. Neale, Eds., Exploring the Legacy of the 1948 Arnhem Land Expedition, ANU E-Press/Australian National University, Canberra, Australia, 2011.

[66] R. L. Specht, "Climate, geology, soils and plant ecology of the northern portion of Arnhem Land," in Botany and Plant Ecology, R. L. Specht and C. P. Mountford, Eds., vol. 3 of Records of the American-Australian Scientific Expedition to Arnhem Land, pp. 314-333, Melbourne University Press, Melbourne, Australia, 1958.

[67] R. L. Specht, R. B. Salt, and S. Reynolds, "Vegetation in the vicinity of Weipa, North Queensland," Proceedings of the Royal Society of Queensland, vol. 88, pp. 17-38, 1977.

[68] R. L. Specht and A. Specht, "Canopy structure in Eucalyptusdominated communities in Australia along climatic gradients," Acta Oecologia, vol. 10, no. 2, pp. 191-213, 1989.

[69] R. L. Specht and A. Specht, "Species richness of sclerophyll (heathy) plant communities in Australia-the influence of overstorey cover," Australian Journal of Botany, vol. 37, no. 4, pp. 337-350, 1989.

[70] R. W. Braithwaite, J. W. Winter, J. A. Taylor, and B. S. Parker, "Patterns of diversity and structure of mammalian assemblages in the Australian tropics," Australian Mammalogy, vol. 8, pp. 171-197, 1985. 
[71] P. C. Catling, "Vertebrates," in Mediterranean-Type Ecosystems. A Data Source Book, R. L. Specht, Ed., pp. 171-197, Kluwer Academic Publishers, Dordrecht, The Netherlands, 1988.

[72] I. L. Ophel, M. Hoppenheit et al., "Effects of ionizing radiation on aquatic organisms," in Report on the Panel on the Effects of Ionizing Radiation on Aquatic Organisms and Ecosystems, Part II, International Atomic Energy Agency, Vienna, Austria, 1976.

[73] A. M. Scott and G. W. Prescott, "Some freshwater algae from Arnhem Land in the Northern Territory of Australia," in Botany and Plant Ecology, R. L. Specht and C. P. Mountford, Eds., vol. 3 of Records of the American-Australian Scientific Expedition to Arnhem Land, pp. 9-136, Melbourne University Press, Melbourne, Australia, 1958.

[74] A. M. Scott and G. W. Prescott, "Some South Australian desmids," Transactions of the Royal Society of South Australia, vol. 75, pp. 55-69, 1952.

[75] G. D. F. Wilson, C. L. Humphrey, D. J. Colgan, K. A. Gray, and R. N. Johnson, "Monsoon-influenced speciation patterns in a species flock of Eophreatoicus Nicholls (Isopoda; Crustacea)," Molecular Phylogenetics and Evolution, vol. 51, no. 2, pp. 349-364, 2009.

[76] M. M. Specht and R. L. Specht, "Bibliographia phytosociologica: Australia," Excerpta Botanica B, vol. 4, no. 1, pp. 1-58, 1962.

[77] R. L. Specht, E. M. Roe, and V. H. Boughton, Eds., "Conservation of major plant communities in Australia and Papua New Guinea," Australian Journal of Botany, Supplementary Series no. 7, 1974.

[78] M. O. Hill, "Reciprocal averaging: an eigen vector method of ordination," Journal of Ecology, vol. 61, pp. 237-249, 1973.

[79] R. L. Specht, A. Specht, M. B. Whelan, and E. E. Hegarty, Conservation Atlas of Plant Communities in Australia, Lismore, Australia, Southern Cross University, 1995.

[80] R. L. Specht and P. Rayson, "Dark Island heath (NinetyMile Plain, South Australia). 1. Definition of the ecosystem," Australian Journal of Botany, vol. 5, pp. 52-85, 1957.

[81] R. H. Groves, "Growth of Themeda australis tussock grassland at St Albans, Victoria," Proceedings of the Royal Society of Victoria, vol. 19, pp. 291-302, 1965.

[82] R. T. Patton, "Ecological studies in Victoria. Part 5. The red box and red stringybark association," Proceedings of the Royal Society of Victoria, vol. 49, pp. 293-307, 1937.

[83] H. T. Clifford and J. J. Mott, "Regenerative processes," in Tropical Plant Communities. Their Resilience, Functioning and Management in Northern Australia, H. T. Clifford and R. L. Specht, Eds., pp. 68-77, The Utah Foundation/Botany Department, University of Queensland, St Lucia, Australia, 1986.

[84] R. L. Specht, "Savannah woodland vegetation in the southeast district of South Australia: the influence of evaporative aerodynamics on the foliage structure of the understorey invaded by introduced annuals," Austral Ecology, vol. 25, no. 6, pp. 588-599, 2000.

[85] R. L. Specht, "Dark Island heath (Ninety-Mile Plain, South Australia). 5. The water relationships in heath vegetation and pastures on the Makin Sand," Australian Journal of Botany, vol. 5, pp. 151-172, 1957.

[86] H. A. Martin and R. L. Specht, "Are mesic communities less drought resistant? A study on moisture relationships in dry sclerophyll forest at Inglewood, South Australia," Australian Journal of Botany, vol. 10, no. 2, pp. 106-118, 1962.
[87] B. B. Carrodus, Some Aspects of the Ecology of Arid South Australia: The Relative Distribution of Atriplex vesicaria Heward ex Benth. and Kochia sedifolia F. v. M., M. Sc. thesis, University of Adelaide, South Australia, Australia, 1962.

[88] B. B. Carrodus and R. L. Specht, "Factors affecting the relative distibution of Atriplex vesicaria and Kochia sedifolia (Chenopodiaceae) in the arid zone of South Australia," Australian Journal of Botany, vol. 13, no. 3, pp. 419-433, 1965.

[89] R. L. Specht and R. Jones, "A comparison of the water use by heath vegetation at Frankston, Victoria, and Dark Island Soak, South Australia," Australian Journal of Botany, vol. 19, no. 3, pp. 311-326, 1971.

[90] W. H. Haines, Experimental Approaches to the Study of Seasonal Root Activity and Phosphorus Nutrition of Australian Heath Plants, M. Sc. thesis, University of Melbourne, Melbourne, Australia, 1967.

[91] R. L. Specht, "Growth indices—Their rôle in understanding the growth, structure and distribution of Australian vegetation," Oecologia, vol. 50, no. 3, pp. 347-356, 1981.

[92] R. L. Specht, "Water use by perennial, evergreen plant communities in Australia and Papua New Guinea," Australian Journal of Botany, vol. 20, no. 3, pp. 273-299, 1972.

[93] R. L. Specht, E. J. Moll, F. Pressinger, and J. Sommerville, "Moisture regime and nutrient control of seasonal growth in Mediterranean ecosystems," in Mediterranean-Type Ecosystems. The Role of Nutrients, F. J. Kruger, D. T. Mitchell, and J. U. M. Jarvis, Eds., pp. 120-132, Springer, Berlin, Germany, 1983.

[94] R. L. Specht, D. J. Yates, J. E. M. Sommerville, and E. J. Moll, "Foliage structure and shoot growth in heathlands in the Mediterranean-type climate of southern Australia and South Africa," Ecologia Mediterranea, vol. 16, pp. 195-207, 1991.

[95] C. Boucher and E. J. Moll, "South African Mediterranean shrublands," in Mediterranean-Type Shrublands, F. di Castri, D. W. Goodall, and R. L. Specht, Eds., vol. 11 of Ecosystems of the World, pp. 233-248, Elsevier, Amsterdam, The Netherlands, 1981.

[96] R. L. Specht, "A comparison of the sclerophyllous vegetation characteristic of Mediterranean type climates in France, California, and Southern Australia. I. Structure, morphology, and succession," Australian Journal of Botany, vol. 17, no. 2, pp. 277-292, 1969.

[97] R. L. Specht, "A comparison of the sclerophyllous vegetation characteristic of Mediterranean type climates in France, California, and Southern Australia. II. Dry matter, energy, and nutrient accumulation," Australian Journal of Botany, vol. 17, no. 2, pp. 293-308, 1969.

[98] P. Wellman and I. McDougall, "Cainozoic igneous activity in eastern australia,” Tectonophysics, vol. 23, no. 1-2, pp. 49-65, 1974.

[99] J. J. Veevers, "Gondwanaland from 650-500 Ma assembly through 320 Ma merger in Pangea to $185-100$ Ma breakup: supercontinental tectonics via stratigraphy and radiometric dating," Earth-Science Reviews, vol. 68, no. 1-2, pp. 1-132, 2004.

[100] R. L. Specht and M. E. Dettmann, "Palaeo-ecology of Australia and current physiological functioning of plant communities," in Time Scales of Biological Responses to Water Constraints: The Case of Mediterranean Biota, J. Roy, J. Aronson, and F. di Castri, Eds., pp. 201-214, SPB Academic Publishing, Amsterdam, The Netherlands, 1995.

[101] R. L. Specht and Y. M. Brouwer, "Seasonal shoot growth of Eucalyptus spp. in the Brisbane area of Queensland (with 
notes on shoot growth and litter fall in other areas of Australia)," Australian Journal of Botany, vol. 23, no. 3, pp. 459-474, 1975.

[102] E. W. Pook, "Canopy dynamics of Eucalyptus maculata Hook. I. Distribution and dynamics of leaf populations," Australian Journal of Botany, vol. 32, no. 4, pp. 387-403, 1984.

[103] E. W. Pook, A. M. Gill, and P. H. R. Moore, "Long-term variation of litter fall, canopy leaf area and flowering in a Eucalyptus maculata forest on the south coast of New South Wales," Australian Journal of Botany, vol. 45, no. 5, pp. 737755, 1997.

[104] R. L. Specht, R. W. Rogers, and A. J. M. Hopkins, "Seasonal growth and flowering rhythms: Australian heathlands," in Heathlands and Related Shrublands. Analytical Studies, R. L. Specht, Ed., vol. 9B of Ecosystems of the World, pp. 5-13, Elsevier, Amsterdam, The Netherlands, 1981.

[105] A. Specht, Temperature Effects on Eucalypt Shoot Growth in the Brisbane Region, Ph.D. thesis, University of Queensland, St Lucia, Australia, 1985.

[106] E. E. Hegarty, Canopy Dynamics of Lianes and Trees in Subtropical Rainforest, Ph.D. thesis, University of Queensland, St Lucia, Australia, 1988.

[107] E. E. Hegarty, "Leaf life-span and leafing phenology of lianes and associated trees during a rainforest succession," Journal of Ecology, vol. 78, no. 2, pp. 300-312, 1990.

[108] E. E. Hegarty, "Leaf litter production by lianes and trees in a sub-tropical Australian rain forest," Journal of Tropical Ecology, vol. 7, no. 2, pp. 201-214, 1991.

[109] R. L. Specht, "Functioning of tropical plant communities: Phenology," in Tropical Plant Communities. Their Resilience, Functioning and Management in Northern Australia, H. T. Clifford and R. L. Specht, Eds., pp. 78-90, Utah Foundation/University of Queensland, Botany Department, St Lucia, Australia, 1986

[110] R. L. Specht, "Foliage projective covers of overstorey and understorey strata of mature vegetation in Australia," Australian Journal of Ecology, vol. 8, no. 4, pp. 433-439, 1983.

[111] R. L. Specht, P. Rayson, and M. E. Jackman, "Dark Island heath (Ninety-mile Plain, South Australia). VI. Pyric succession: changes in composition, coverage, dry weight, and mineral nutrient status," Australian Journal of Botany, vol. 6, no. 1, pp. 59-88, 1958.

[112] R. L. Specht and D. G. Morgan, "The balance between the foliage projective covers of overstorey and understorey strata in Australian vegetation," Australian Journal of Ecology, vol. 6, no. 2, pp. 193-202, 1981.

[113] R. L. Specht, G. N. Batianoff, and R. D. Reeves, "Vegetation structure and biodiversity along the eucalypt forest to rainforest continuum on the serpentinite soil catena in a subhumid area of Central Queensland, Australia," Austral Ecology, vol. 31, no. 3, pp. 394-407, 2006.

[114] R. L. Specht, "Structure and species richness in wetland continua on sandy soils in subtropical and tropical Australia," Austral Ecology, vol. 34, no. 7, pp. 761-772, 2009.

[115] T. J. Danaher, J. O. Carter, K. D. Brook, A. Peacock, and G. S. Dudgeon, "Broad-scale vegetation mapping using NOAAAVRRR imagery," in Proceedings of the 8th Australasian Remote Sensing Conference, vol. 3, pp. 126-137, Wellington, New Zealand, 1992.

[116] Queensland Department of Environment and Resource Management, Land Cover Change in Queensland 2008-09: a Statewide Landcover and Trees Study (SLATS) Report,
Department of Environment and Resource Management, Brisbane, Australia, 2011.

[117] J. R. Garratt, R. J. Francey, I. C. McIlroy et al., "International Turbulence Comparison Experiment (Australia 1976)— Meteorological Support Data," Technical Paper 37, CSIRO Division of Atmospheric Physics, 1979.

[118] J. K. Marshall, "Drag measurements in roughness arrays of varying density and distribution," Agricultural Meteorology, vol. 8, no. C, pp. 269-292, 1971.

[119] R. L. Specht and A. Specht, "Species richness of overstorey strata in Australian plant communities-the influence of overstorey growth rates," Australian Journal of Botany, vol. 37, no. 4, pp. 321-336, 1989.

[120] A. S. Watt, "Pattern and process in the plant community," Journal of Ecology, vol. 35, pp. 1-22, 1947.

[121] A. M. Gill, R. H. Groves, and I. R. Noble, Eds., Fire and the Australian Biota, Australian Academy of Science, Canberra, Australia, 1981.

[122] P. Jaccard, "Die statistische-floristische Methode als Grundlage der Pflanzensoziologie," Handbuch Biol. Arbeitsmeth. Abderhalden, vol. 11, no. 5, pp. 165-202, 1928.

[123] B. Hopkins, "The species-area relations of plant communities," Journal of Ecology, vol. 43, no. 2, pp. 409-426, 1955.

[124] R. H. Whittaker, "Evolution and measurement of species diversity," Taxon, vol. 21, pp. 213-251, 1972.

[125] J. Braun-Blanquet, Plant Sociology, McGraw-Hill, New York, NY, USA, 1932.

[126] G. Long, Diagnostic Phyto-Écologique et Aménagement du Territoire, Masson, Paris, France, 1974.

[127] C. S. Christian, "Regional land surveys," Journal of the Australian Institute of Agricultural Science, vol. 18, pp. 140-147, 1952.

[128] C. S. Christian and R. A. Perry, "The systematic description of plant communities by the use of symbols," Journal of Ecology, vol. 41, no. 1, pp. 100-105, 1953.

[129] A. Specht, Resource Material, vol. 2 of Big Scrub Conservation Strategy, New South Wales National Parks and Wildlife Service, Sydney, Australia, 1988.

[130] R. L. Specht, "Species richness of rainforest stands on non-serpentinite and serpentinite substrates in the Rockhampton-Marlborough area of Central Queensland," Proceedings of the Royal Society of Queensland, vol. 113, pp. 17-35, 2007.

[131] R. L. Specht, Ed., Mediterranean-type Ecosystems. A Data Source Book, Kluwer Academic, Dodrecht, The Netherlands, 1988.

[132] R. L. Specht, R. L. Specht, and R. L. Specht, "Species richness of vascular plants and vertebrates in relation to canopy productivity," in Plant-Animal Interactions in MediterraneanType Ecosystems, M. Arianoutsou and R. H. Groves, Eds., pp. 15-24, Kluwer Scientific, Dodrecht, The Netherlands, 1994.

[133] R. L. Specht and D. J. Yates, "Climatic control of structure and phenology of foliage shoots indicotyledonous overstorey and understorey strata of subtropical plant communities in eastern Australia," Acta Oecologia, vol. 11, pp. 215-233, 1990.

[134] A. Specht and R. L. Specht, "Australia: biodiversity of ecosystems," in Encyclopedia of Biodiversity, S. Levin, Ed., pp. 307-324, Academic Press, San Diego, Calif, USA, 2001.

[135] A. Specht and R. L. Specht, "Australia: biodiversity of ecosystems," in Encyclopedia of Biodiversity, S. Levin, Ed., Elsevier, Kidlington, UK, 2nd edition, 2011. 
[136] G. H. Orians and A. V. Milewski, "Ecology of Australia: the effects of nutrient-poor soils and intense fires," Biological Reviews, vol. 82, no. 3, pp. 393-423, 2007.

[137] A. Specht and R. L. Specht, "Species richness and canopy productivity of Australian plant communities," Biodiversity and Conservation, vol. 2, no. 2, pp. 152-167, 1993.

[138] A. Specht and R. L. Specht, "Biodiversity of overstorey trees in relation to canopy productivity and stand density in the climatic gradient from warm temperate to tropical Australia," Biodiversity Letters, vol. 2, no. 2, pp. 39-45, 1994.

[139] R. L. Specht, R. I. Grundy, A. Specht, and R. Berliner, "Species richness of plant communities: relationship with community growth and structure," Israel Journal of Botany, vol. 39, pp. 465-480, 1990.

[140] G. N. Batianoff, R. D. Reeves, and R. L. Specht, "The effect of serpentine on vegetation structure, species diversity and endemism in Central Queensland," in The Ecology of Ultramafic and Metalliferous Areas, T. Jaffré, R. D. Reeves, and T. Becquer, Eds., pp. 44-50, Centre ORSTOM de Nouméa, New Caledonia, 1997.

[141] D. J. Connor, B. R. Tunstall, and R. Van Den Driessche, "An analysis of photosynthetic response in a brigalow forest," Photosynthetica, vol. 5, no. 3, pp. 218-225, 1971.

[142] D. Doley, D. J. Yates, and G. L. Unwin, "Photosynthesis in an Australian rainforest tree, Argyrodendron peralatum, during the rapid development and relief of water deficits in the dry season," Oecologia, vol. 74, no. 3, pp. 441-449, 1987.

[143] D. Doley, G. L. Unwin, and D. J. Yates, "Spatial and temporal distribution of photosynthesis and transpiration by single leaves in a rainforest tree, Argyrodendron peralatum," Australian Journal of Plant Physiology, vol. 15, no. 1-2, pp. 317-326, 1988.

[144] M. L. Cody, "Bird diversity within and among Australian heathlands," in Plant-Animal Interactions in Mediterraneantype Ecosystems, M. Arianoutsou and R. H. Groves, Eds., pp. 47-61, Kluwer Scientific, Dodrecht, The Netherlands, 1994.

[145] M. L. Cody, "Mulga bird communities. I.Species composition and predictability across Australia," Australian Journal of Ecology, vol. 19, no. 2, pp. 206-219, 1994.

[146] E. R. Pianka and J. J. Schall, "Species densities of Australian vertebrates," in Ecological Biogeography of Australia, A. Keast, Ed., pp. 1675-1694, Junk, The Hague, The Netherlands, 1981.

[147] R. L. Specht and M. J. Tyler, "The species richness of vascular plants and amphibia in major plant communities in temperate and tropical Australia: relationship with annual biomass production," International Journal of Ecology, vol. 2010, Article ID 635852, 17 pages, 2010.

[148] S. J. Edmonds and M. M. Specht, "Dark Island heathland, South Australia: faunal rhythms," in Heathlands and Related Shrublands. Analytical Studies, R. L. Specht, Ed., vol. 9B of Ecosystems of the World, pp. 15-27, Elsevier Science, Amsterdam, The Netherlands, 1981.

[149] P. Greenslade and J. D. Majer, Eds., Soil and Litter Invertebrates of Australian Mediterranean-type Ecosystems, Bulletin No. 12, Western Australian Institute of Biology, Perth, Australia, 1985.

[150] J. D. Majer and P. Greenslade, "Soil and litter invertebrates," in Mediterranean-type Ecosystems. A Data Source Book, R. L. Specht, Ed., pp. 197-226, Kluwer Academic, Dodrecht, The Netherlands, 1988.

[151] A. S. George, A. J. M. Hopkins, and N. G. Marchant, "The heathlands of Western Australia," in Heathlands and Related Shrublands. Descriptive Studies, R. L. Specht, Ed., vol. 9A of
Ecosystems of the World, pp. 211-230, Elsevier, Amsterdam, The Netherlands, 1979.

[152] R. L. Specht, "A heritage inverted, our flora endangered," Search, vol. 6, no. 11-12, pp. 472-477, 1975.

[153] R. L. Specht, H. T. Clifford, and R. W. Rogers, "Species richness in a eucalypt open-woodland on North Stradbroke Island, Queensland. The effect of overstorey and fertilizer, 1965 -1984," in Focus on Stradbroke. New Information on North Stradbroke Island and Surrounding Areas, 1974-1984, R. J. Coleman, J. Covacevich, and P. Davie, Eds., pp. 267-677, Boolarong Press, Brisbane, Australia, 1984.

[154] D. J. Connor and G. L. Wilson, "Response of a coastal Queensland heath community to fertilizer application," Australian Journal of Botany, vol. 16, no. 1, pp. 117-123, 1968.

[155] E. M. Heddle and R. L. Specht, "Dark Island heath (NinetyMile Plain, South Australia). 8. The effect of fertilizers on composition and growth, $1950-1972$," Australian Journal of Botany, vol. 23, no. 1, pp. 151-164, 1975.

[156] R. L. Specht and H. T. Clifford, "Plant invasion and soil seed banks: control by water and nutrients," in Biogeography of Mediterranean Invasions, R. H. Groves and F. di Castri, Eds., pp. 191-204, SPB Academic Publishing, Amsterdam, The Netherlands, 1991.

[157] D. Lamb, "Soil nitrogen mineralisation in a secondary rainforest succession," Oecologia, vol. 47, no. 2, pp. 257-263, 1980.

[158] R. L. Specht, "Phosphate pollution and soil nitrate: threats to biodiversity in Australia," in Landscape Health of Queensland, A. J. Franks, J. Playford, and A. Shapcott, Eds., pp. 53-70, Royal Society of Queensland, Brisbane, Australia, 2002.

[159] R. L. Specht and J. B. Cleland, "Flora conservation in South Australia. I. The preservation of plant formations and associations recorded in South Australia," Transactions of the Royal Society of South Australia, vol. 85, pp. 177-196, 1961.

[160] R. L. Specht, "Conservation: Australian heathlands," in Heathlands and Related Shrublands. Analytical Studies, R. L. Specht, Ed., vol. 9B of Ecosystems of the World, pp. 235-240, Elsevier Science, Amsterdam, The Netherlands, 1981.

[161] D. Doley, Plant-Fluoride Relationships, Inkata Press, Melbourne, Australia, 1986.

[162] J. F. McGregor and H. B. Newcombe, "Dose-response relationships for yields of major eye malformations following low doses of radiation to trout sperm," Radiation Research, vol. 49, no. 1, pp. 155-169, 1972.

[163] R. L. Specht, "The Arnhem Land Escarpment:-A National Monument," Ranger Uranium Environmental Inquiry, Submission June 1976, Sydney, Australia, 1976.

[164] R. G. Barry and R. J. Chorley, Atmosphere, Weather and Climate, Methuin, London, UK, 2nd edition, 1971.

[165] Bureau of Meteorology, Manual of Meteorology. Part 1. General Meteorology, Australian Government Publishing Service, Canberra, Australia, 1975.

[166] R. L. Specht, "Geosphere-biosphere interaction in terrestrial ecosystems," in Global Change, K. D. Cole, Ed., pp. 169-176, Australian Academy of Science, Canberra, Australia, 1988.

[167] R. L. Specht and A. Specht, "Global warming: predicted effects on structure and species richness of mediterranean ecosystems in southern Australia," in Time Scales of Biological Responses to Water Constraints: The Case of Mediterranean Biota, J. Roy, J. Aronson, and F. di Castri, Eds., pp. 215-237, SPB Academic Publishing, Amsterdam, The Netherlands, 1995. 

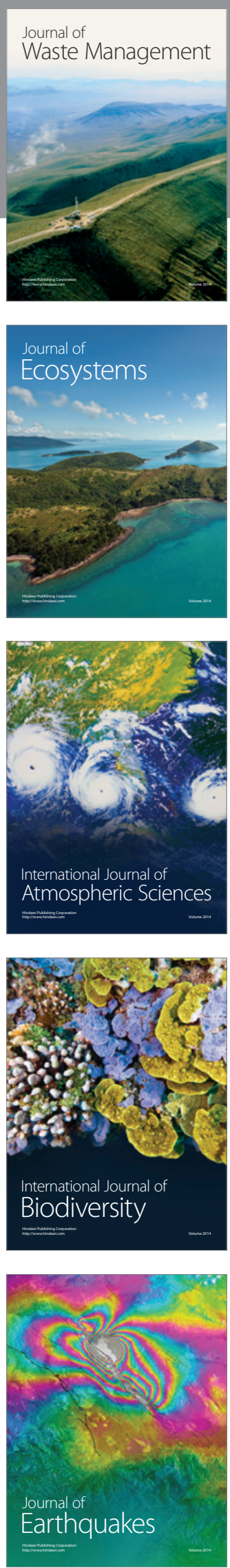
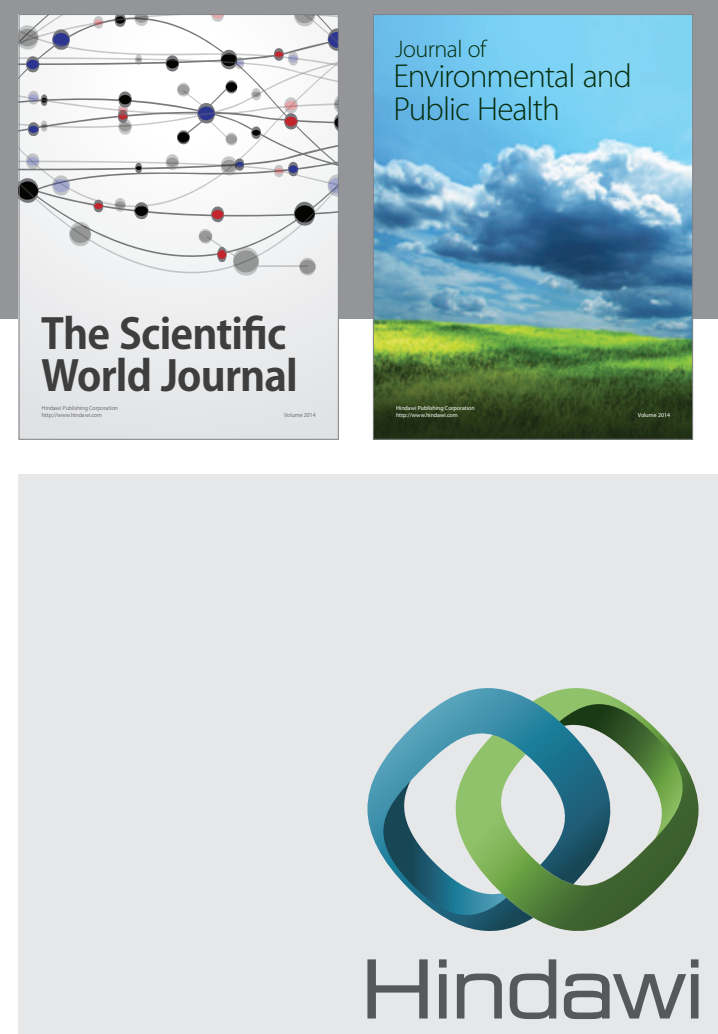

Submit your manuscripts at

http://www.hindawi.com
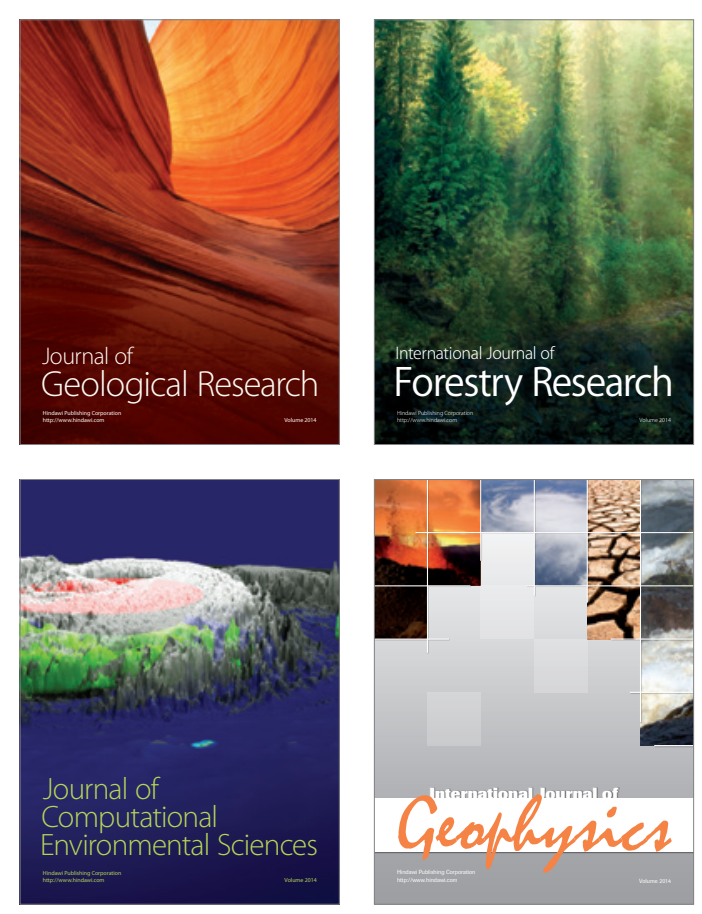
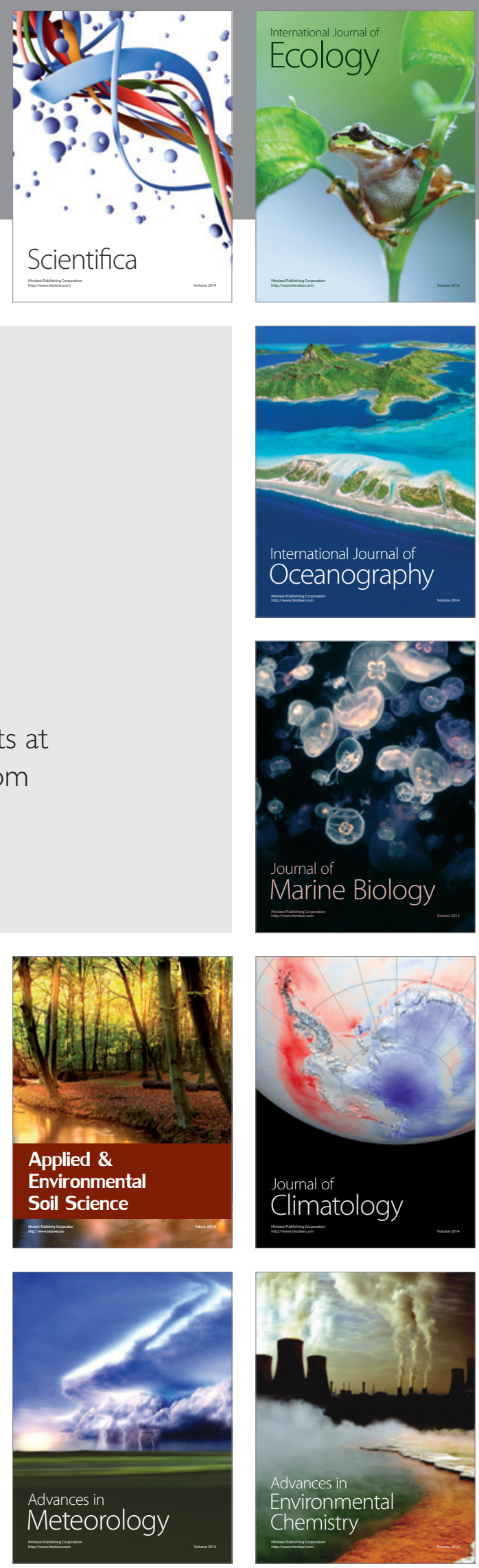